\title{
Potential Antiosteoporotic Agents from Plants: A Comprehensive Review
}

\author{
Min Jia, ${ }^{1}$ Yan Nie, ${ }^{1,2}$ Da-Peng Cao, ${ }^{1}$ Yun-Yun Xue, ${ }^{1}$ Jie-Si Wang, ${ }^{1}$ \\ Lu Zhao, ${ }^{1,2}$ Khalid Rahman, ${ }^{3}$ Qiao-Yan Zhang, ${ }^{1}$ and Lu-Ping Qin ${ }^{1}$ \\ ${ }^{1}$ Department of Pharmacognosy, School of Pharmacy, Second Military Medical University, Shanghai 200433, China \\ ${ }^{2}$ Department of Pharmacy, Fujian University of Traditional Chinese Medicine, Fuzhou 350108, China \\ ${ }^{3}$ School of Pharmacy and Biomolecular Sciences, Liverpool John Moores University, Byrom Street, Liverpool L3 3AF, UK
}

Correspondence should be addressed to Qiao-Yan Zhang, zqy1965@163.com and Lu-Ping Qin, qinsmmu@126.com

Received 10 August 2012; Accepted 30 October 2012

Academic Editor: Olumayokun A. Olajide

Copyright () 2012 Min Jia et al. This is an open access article distributed under the Creative Commons Attribution License, which permits unrestricted use, distribution, and reproduction in any medium, provided the original work is properly cited.

\begin{abstract}
Osteoporosis is a major health hazard and is a disease of old age; it is a silent epidemic affecting more than 200 million people worldwide in recent years. Based on a large number of chemical and pharmacological research many plants and their compounds have been shown to possess antiosteoporosis activity. This paper reviews the medicinal plants displaying antiosteoporosis properties including their origin, active constituents, and pharmacological data. The plants reported here are the ones which are commonly used in traditional medical systems and have demonstrated clinical effectiveness against osteoporosis. Although many plants have the potential to prevent and treat osteoporosis, so far, only a fraction of these plants have been thoroughly investigated for their physiological and pharmacological properties including their mechanism of action. An attempt should be made to highlight plant species with possible antiosteoporosis properties and they should be investigated further to help with future drug development for treating this disease.
\end{abstract}

\section{Introduction}

Osteoporosis is a systemic skeletal disease characterized by low bone mineral density (BMD) and microarchitectural deterioration of bone tissue, leading to a consequent increase in bone fragility and fracture risk. Hypogonadism is the most well-established cause of osteoporosis, which is usually thought to be an age-adjusted symptom [1]. In recent years, it has become a major health hazard afflicting more than 200 million people worldwide and has one of the highest incidence of all diseases in the elderly population [2]. The Health Departments in many countries are spending large amounts of money investigating new antiosteoporosis drugs every year.

Based on the principles of physiological bone regeneration and the role of osteoblasts and osteoclasts in the process, it is obvious that the rate of supply of new osteoblasts and osteoclasts, and the timing of the death of these cells by apoptosis are critical determinants of bone regeneration [3]. The activities of these cells are mainly associated with sex steroid deficiency, senescence, and glucocorticoid excess; furthermore, at menopause, the rate of bone remodeling increases precipitously. The loss of sex steroids upregulates the formation of osteoclasts and osteoblasts in the marrow by upregulating the production and action of cytokines, including IL-6, TNF, IL-1, and macrophage colony stimulating factors (M-CSF) which mediate osteoclastogenesis and osteoblastogenesis [4]. The imbalances between bone resorption and formation are due to an extension of the working lifespan of the osteoclasts and shortening of the working lifespan of the osteoblasts. The amount of bone formed during each remodeling cycle decreases with age in both sexes. In aging women, even in extreme old age, bone turnover is most likely increased by secondary hyperparathyroidism or by the continuing effect of estrogen deficiency [5]. Glucocorticoid excess decreases intestinal calcium absorption and hypercalciuria due to defective vitamin D metabolism. These changes result in increased bone resorption, decreased osteoblast proliferation and biosynthetic activity, and sex-steroid deficiency, 
as well as hyperparathyroidism [6]. Glucocorticoid excess has a suppressive effect on osteoblastogenesis in the bone marrow and also promotes the apoptosis of osteoblasts and osteocytes. Glucocorticoids directly suppress BMP-2 (bone morphogenetic protein-2) and $\mathrm{Cbf} \alpha-1$ (core binding factor $\alpha 1$ ), two critical factors for osteoblastogenesis, and may also decrease the production of IGFs (insulin-like growth factors) while stimulate the transcriptional activity of PPAR$\gamma 2$ (peroxisome proliferator-activated receptor- $\gamma 2$ ) [7].

There are certain risk factors which differ among individuals and are linked to the development of osteoporosis and contribute to the likelihood of developing the disease. These factors can be divided into two categories, the first being nonmodifiable factors such as gender, age, body size, ethnicity, and family history, the other modifiable factors are sex hormones, anorexia nervosa, calcium and vitamin D intake, medication use, lifestyle, cigarette smoking, and alcohol intake, and so forth [2]. Physical exercise, dietary supplement, and pharmacotherapy are usually used for prevention and treatment of osteoporosis. The pharmacotherapy for osteoporosis is usually focused on accommodating the estrogen level or bone remodel. The mechanisms involves many aspects, such as stimulating parathyroid hormone (PTH) synthesizes; inducing the expression of OPG (osteoprotegerin); decreasing IL-1, 4, 6, and M-CSF; increasing estrogens or like-estrogens; supplementing $\mathrm{Ca}, \mathrm{P}$ in bones; to inhibit the proliferation of osteoclast and induce osteoclast apoptosis; and to enhance the proliferation and differentiation of osteoblast. The drugs used mainly include estrogen, parathyroid hormone $(\mathrm{PTH})$, various bisphosphonates, the selective oestrogen-receptor modulators (SERM) raloxifene, calcitonin, sodium fluoride, and calcium and vitamin D [8].

Calcium supplementation alone provides small beneficial effects on bone mineral density through postmenopausal life and may slightly reduce fracture rates, and vitamin D may be effective in deficient individuals [9]. The longterm hormone therapy for osteoporosis of postmenopausal women is controversial, because of increases in the risk of breast carcinoma, endometrial cancer, and cardiovascular disease. In postmenopausal women with osteoporosis and cardiovascular risk factors, combined oestrogen and progestagen or estrogen alone therapy should be avoided in favor of alternative antiresorptive agents. Hormone therapy remains an option only for short-term early use around the menopause in symptomatic women with high rates of risk fracture [10]. Bisphosphonates can reduce the risk of vertebral fractures and non-vertebral fractures including hip fractures. The dosing regimen (which require the patients to fast and remain upright for at least $30 \mathrm{~min}$ ) and upper gastrointestinal side effects are often limiting factors in daily bisphosphonate therapy. Their duration of physiological effect is unclear, but bone turnover makers can remain suppressed for at least 5 years after their discontinuation [11]. Selective oestrogen-receptor modulators (including raloxifene, arzoxifene and lasofoxifene) are a chemically diverse set of compounds that do not have the steroid structure of oestrogen, but have a tertiary structure that allows binding to the oestrogen receptor to exert selective agonist or antagonist effects on different oestrogen target tissue. The most studied is raloxifene; its effects on markers of bone turnover and bone mineral density have generally been less than with biophosphonate therapy, so it should probably mainly be used in postmenopausal women with milder osteoporosis or in those with predominantly spinal osteoporosis. Potential side effects include an increase risk of venous thrombosis similar to that with hormone therapy and exacerbation of hot flushes [12]. The previously mentioned therapies act mainly to reduce bone resorption and the anabolic agent parathyroid hormone (PTH) mainly stimulates bone formation. The clinical trials in postmenopausal women showed PTH reduced the risk of fractures with $20 \mu \mathrm{g}$ dose. However, the benefit in terms of bone mineral density seemed to wane after discontinuation unless followed by an antiresorptive agent [13]. In addition, strontium ranelate is a fairly new antiosteoporotic agent that has been approved in the European Union for the treatment of postmenopausal osteoporosis. It increase bone formation while reducing bone resorption, however its mechanism of action remains unclear. The clinical trials in postmenopausal women show that strontium ranelate reduces the risk of fractures and was well tolerated apart from a low rate of gastrointestinal sideeffects and an increased risk of venous thrombosis [14].

Estrogen, bisphosphonates, calcitonin, calcium products, ipriflavone, and anabolic steroids are clinically used as effective medications [15]; however, each of them has established some side effects. Many medicinal plants have long been used to prevent and treat osteoporosis in many countries. These natural medicines derived from plants have fewer side effects and are more suitable for long-term use than synthesized drugs. These plant medicines containing numerous chemical constituents usually exert their therapeutic effects through multipathways and have multitargets, this property is parallel with the multiple factors of osteoporosis pathogenesis. In this paper, we summarize recent studies about antiosteoporotic medicinal plants with particular emphasis on the chemical constituents, mechanisms of action, and therapeutic applications. This will provide more information for the applications of medicinal plants in the prevention and treatment of osteoporosis.

\section{Materials and Methods}

The following computerized databases were searched from their inception to May 2012: MEDLINE (PUBMED), ALT HEALTH WATCH (EBSCO), and Google scholar. Text word search of titles and abstracts was conducted using the following entries in various conjunction or disjunction: osteoporosis, osteoblast, osteoclast, herbs, medicinal plant, natural product, herbal medicine, plant medicine, and phytomedicine. Each study included in this paper satisfies the following criteria: (i) the studies on antiosteoporotic activity were conducted on animal, or cultured osteoblast and osteoclast, and (ii) plant extracts, or compounds isolated from plant. The exclusion criteria consisted of (i) the herb studied was an herbal formula (i.e., neither a single herb nor a single herbal compound), (ii) the articles were not written in English or translated into English. Two reviewers 
independently extracted the data and performed quality assessment.

\section{Results}

3.1. Medicinal Herbs. As shown in Table 1, literature survey showed that 76 medicinal plants were reported in ethnopharmacological studies for their potential benefits in osteoporosis treatment. These plants were distributed among 44 families, including Amaranthaceae (1 spp), Amaryllidaceae (1 spp), Apiaceae (6 spp), Berberidaceae (5 spp), Brassicaceae (1 spp), Campanulaceae (1 spp), Caprifoliaceae (1 spp), Compositae (4spp), Convolvulaceae (1 spp), Davalliaceae (1 spp), Dicksoniaceae (1 spp), Dioscoreaceae (2 spp), Dipsacaceae (1 $\mathrm{spp})$, Ericaceae (1 spp), Eucommiaceae (1 spp), Euphorbiaceae (1 spp), Fabaceae (11spp), Ginkgoaceae (1 spp), Juglandaceae (1 spp), Labiatae (2spp), Lauraceae (1 spp), Liliaceae (5 spp), Lythraceae (1 spp), Malvaceae (1 spp), Menispermaceae (1 spp), Myrsinaceae (1 spp), Oleaceae (1 spp), Orchidaceae (1 spp), Orobanchaceae (2 spp), Pleurotaceae (1 spp), Polypodiaceae (1 spp), Punicaceae (1 spp), Ranunculaceae (2 spp), Rosaceae (2 spp), Rubiaceae (1 spp), Rutaceae (2 spp), Scrophulariaceae (1 spp), Solanaceae (1 spp), Taxaceae (1 spp), Theaceae (1 spp), Ulmaceae (2 spp), Verbenaceae (1 spp), Vitaceae (1 spp), and Zingiberaceae (1 spp). The evaluations of antiosteoporotic activity of these plants are based on the animal experiment (58 spp), cultured osteoblast, and osteoclast in vitro (18 spp). The more highly represented botanic families were: Fabaceae (11 spp), Apiaceae (6 spp), Liliaceae (5 spp), and Compositae (4 spp). Among plant parts, root and rhizome (28 spp) were maximally utilized for antiosteoporosis. Among various parts of plants used in bone metabolism regulation, are root and rhizome (28 spp), fruit and seed (21 spp), stem and bark (13 spp), leaf (7 $\mathrm{spp})$, whole plant and aerial parts (6spp), and flower (1 spp). Multiple references were consulted for detailed information on research status of 10 plant species which are discussed below.

3.1.1. Epimedium Plants. Epimedium (Berberidaceae) is a low-growing, deciduous, perennial plant. The leaves of $E$. brevicornum Maxim., E. sagittatum (Sieb.et Zucc.) Maxim., E. pubescens Maxim., E. wushanense T. S. Ying, and E. koreanum Nakai have long been used to prevent and treat osteoporosis and other menopause diseases in China. These are the most frequently used herb drugs in antiosteoporotic Chinese traditional medicine formula [16]. Flavonoids including icariin, epimedin B, and epimedin C (Figure 1) are the main antiosteoporotic constituents, which inhibit bone resorption, stimulate bone formation, suppress urinary calcium excretion, and accordingly prevent osteoporosis without hyperplastic effects on the uterus in the ovariectomized (OVX) rat model [17]. The flavonoids from Epimedium plants possess an estrogen-like activity and modulate the bone metabolism through estrogen receptor pathway, and may improve the development of osteoblasts by promoting the ALP (alkaline phosphatase) activity through regulating the expression of IL-6, OPG, RANKL (receptor activator of nuclear factor- $\kappa \mathrm{B}$ ligand), M-CSF, Cbf $\alpha 1$ (core binding factor $\alpha 1$ ), BMP-2 and SMAD4 involved in the bone remodel and modulate proliferation and activity of osteoblasts and osteoclasts $[18,19]$. Epimedium flavonoids enhance the mRNA expression of BMP-2, BMP-4, Runx2 (Runt-related transcription factor 2), and cyclinD1, all of which are BMP or Wnt-signaling pathway related regulators, indicating that Epimedium flavonoids exerts promoting effects on osteogenic differentiation, which plausibly functions via the BMP and $\mathrm{Wnt} / \beta$-catenin signaling pathways [20].

Icariin (Figure 1), the main active flavonoid glucoside isolated from Epimedium plant, is found to have a therapeutic effect on osteoporosis in ovariectomy rat models and postmenopausal women and has been shown to suppress the loss of bone mass and strength in distal femur in tibia following OVX through increasing the mRNA expression ratio of OPG/RANKL [21, 22]. Icariin increases estrogen receptor (ER) dependent cell proliferation, ALP activity, and the OPG/RANKL ratio in UMR 106 cells, and increases ER $\alpha$ phosphorylation, showing that icariin exerts anabolic effects in bone possibly by activating ER [23]. In addition, icariin decreases the TRAP activity of osteoclasts, reduces the size of LPS-induced osteoclasts formation without inhibition of cell viability, inhibits LPS-induced bone resorption and the expression of IL- 6 and TNF- $\alpha$. The synthesis of cyclooxygenase type-2 (COX-2) and prostaglandin $\mathrm{E}_{2}\left(\mathrm{PGE}_{2}\right)$, and expression of LPS-induced hypoxia inducible factor- $1 \alpha$ $(\mathrm{HIF}-1 \alpha)$ in osteoclasts, LPS-mediated activation of the p38 and JNK on osteoclasts is also inhibited. It also reduces the LPS-induced activation of ERK $1 / 2$ and $\mathrm{I} \kappa-\mathrm{B} \alpha$, indicating that icariin has an in vitro inhibitory effect on osteoclasts differentiation that can prevent inflammatory bone loss by suppressing activation of the p38 and JNK pathway [24].

Ikarisoside A (Figure 1), a natural flavonoid isolated from E. koreanum, exerts antioxidant potential and antiinflammatory effects in LPS-stimulated bone marrowderived macrophage precursor cells and RAW 264.7 cells, also inhibits osteoclastogenesis in RANKL-stimulated RAW 264.7 cells as well as in bone marrow-derived macrophages [25]. Ikarisoside A has been found to decrease the osteoclastspecific genes, like matrix metalloproteinase 9 (MMP-9), tartrate-resistant acid phosphatase (TRAP), receptor activator of NF- $\kappa \mathrm{B}$ (RANK), and cathepsin $\mathrm{K}$, and blocks the resorbing capacity of RAW 264.7 cells on calcium phosphatecoated plates, and inhibits the RANKL-mediated activation of NF- $\kappa \mathrm{B}, \mathrm{JNK}$, and Akt. This indicates that Ikarisoside A has potential for use in treatment of diseases involving abnormal bone lysis such as osteoporosis, rheumatoid arthritis, and periodontal bone erosion [26].

3.1.2. Glycine $\max$ L. Glycine max L. (Fabaceae) originally grows in the southwest of Asia, and is now widely planted in warm areas. Its seed, also called soybeanis a common dietary supplement, and contains plenty of nutritional substances, such as proteins and flavonoids including genistein, daidzein and biochanin A (Figure 2). The soy flavonoids which are structurally and functionally related to 17-beta-estradiol have strong effects on bone metabolism in postmenopausal 
TABLE 1: Antiosteoporotic medicinal plants.

\begin{tabular}{|c|c|c|c|c|c|}
\hline Family & Scientific name & $\begin{array}{l}\text { Plant parts } \\
\text { used }\end{array}$ & $\begin{array}{l}\text { Reported relevant } \\
\text { ethnomedical uses }\end{array}$ & $\begin{array}{l}\text { Pharmacological study/chemical } \\
\text { constituents }\end{array}$ & Reference \\
\hline Amaranthaceae & $\begin{array}{l}\text { Achyranthes bidentata } \\
\text { Blume }\end{array}$ & Root & Bone related diseases & $\begin{array}{l}\text { Decrease bone loss in OVX rats by } \\
\text { inhibiting osteoclast formation/oleanolic } \\
\text { acid glycosides, ecdysone and allantoin }\end{array}$ & {$[123,124]$} \\
\hline Amaryllidaceae & $\begin{array}{l}\text { Curculigo orchioides } \\
\text { Gaertn. }\end{array}$ & Rhizome & Impotence, tinnitus & $\begin{array}{l}\text { Decrease bone loss by inhibiting bone } \\
\text { resorption/phenolic glycosides }\end{array}$ & {$[106,125]$} \\
\hline Apiaceae & $\begin{array}{l}\text { Cnidium monnieri } \\
\text { (L.) Cuss. }\end{array}$ & Fruit & $\begin{array}{l}\text { Impotence, lumbar } \\
\text { pain }\end{array}$ & $\begin{array}{l}\text { Reverse prednisone-induced bone mass } \\
\text { loss, inhibit the high bone turnover; } \\
\text { enhance osteoblastic proliferation and } \\
\text { differentiation, inhibit formation and } \\
\text { maturation of osteoclast/coumarins }\end{array}$ & {$[87,126,127]$} \\
\hline Apiaceae & Cuminum cyminum L. & Fruit & $\begin{array}{l}\text { Toothache, diarrhea, } \\
\text { epilepsy }\end{array}$ & $\begin{array}{l}\text { Prevent ovariectomy-induced bone } \\
\text { loss/ } \beta \text {-sitosterol, stigmasterol, luteolin } \\
\text { and apigenin }\end{array}$ & {$[128]$} \\
\hline Apiaceae & Ferula hermonis Boiss & Root & Frigidity, impotence & $\begin{array}{l}\text { Prevent bone loss caused by severe } \\
\text { estrogen deficiency by regulating calcium } \\
\text { mobilization and mitochondrial } \\
\text { permeability/daucane sesquiterpenes, } \\
\text { ferutinin }\end{array}$ & [129] \\
\hline Apiaceae & $\begin{array}{l}\text { Angelica sinensis } \\
\text { (Oliv.) Diels }\end{array}$ & Root & $\begin{array}{l}\text { Hematopoietic, } \\
\text { abnormal or painful } \\
\text { menstruation, other } \\
\text { women's diseases }\end{array}$ & $\begin{array}{l}\text { Increase ALP activity and synthesis of } \\
\text { collagenase type I of } \\
\text { osteoblast/ligustilide, butylidene } \\
\text { phihalide, ferulic acid }\end{array}$ & {$[130]$} \\
\hline Araliaceae & $\begin{array}{l}\text { Panax notoginseng } \\
\text { (Burk.) F. H. Chen }\end{array}$ & Root & $\begin{array}{l}\text { Trauma, injury of } \\
\text { muscles, bone } \\
\text { fracture }\end{array}$ & $\begin{array}{l}\text { Prevent bone loss and deterioration of } \\
\text { trabecular microarchitecture, stimulate } \\
\text { proliferation and differentiation of } \\
\text { osteoblast/triterpene saponins }\end{array}$ & {$[131,132]$} \\
\hline Araliaceae & $\begin{array}{l}\text { Acanthopanax } \\
\text { senticosus (Rupr. et } \\
\text { Maxim.) Harms }\end{array}$ & Stem & $\begin{array}{l}\text { Hypertension, } \\
\text { rheumatism, ischemic } \\
\text { heart disease, diabetes }\end{array}$ & $\begin{array}{l}\text { Decrease bone loss in postmenopausal } \\
\text { women/acanthosides, eleutherosides, } \\
\text { senticoside, triterpen saponin, flavones }\end{array}$ & {$[133]$} \\
\hline Berberidaceae & $\begin{array}{l}\text { Epimedium } \\
\text { brevicornu Maxim }\end{array}$ & Leaf & \multirow{4}{*}{$\begin{array}{l}\text { Impotence, } \\
\text { prospermia, } \\
\text { hyperdiuresis, } \\
\text { osteoporosis, } \\
\text { menopause } \\
\text { syndrome, rheumatic } \\
\text { arthritis, } \\
\text { hypertension and } \\
\text { chronic tracheitis }\end{array}$} & \multirow{4}{*}{ See section 3.1 .1} & \multirow{4}{*}[16-26]{} \\
\hline Berberidaceae & $\begin{array}{l}\text { Epimedium koreanum } \\
\text { Nakai }\end{array}$ & Leaf & & & \\
\hline Berberidaceae & $\begin{array}{l}\text { Epimedium pubescens } \\
\text { Maxim }\end{array}$ & Leaf & & & \\
\hline Berberidaceae & $\begin{array}{l}\text { Epimedium } \\
\text { sagittatum (Sieb. et } \\
\text { Zucc.) }\end{array}$ & Leaf & & & \\
\hline Berberidaceae & Berberis aristata DC & Stem bark & $\begin{array}{l}\text { Menopausal } \\
\text { disorders, } \\
\text { osteoporosis }\end{array}$ & $\begin{array}{l}\text { Decrease bone loss/berberine chloride, } \\
\text { palmatine chloride, magnoflavine, } \\
\text { canadine, berberastine, obaberine, } \\
\text { columbavine and talifendine }\end{array}$ & {$[134,135]$} \\
\hline Brassicaceae & $\begin{array}{l}\text { Lepidium meyenii } \\
\text { Walp. }\end{array}$ & Root & $\begin{array}{l}\text { Hot flushes, tender } \\
\text { breast, vaginal } \\
\text { dryness, osteoporosis }\end{array}$ & $\begin{array}{l}\text { Improve the bone mass in OVX } \\
\text { rats/macaridine, macaene, macamides, } \\
\text { and maca alkaloids }\end{array}$ & {$[136,137]$} \\
\hline Campanulaceae & $\begin{array}{l}\text { Platycodon } \\
\text { grandiflorum (Jacq.) } \\
\text { A. DC. }\end{array}$ & Root & $\begin{array}{l}\text { Cough, chronic } \\
\text { diseases }\end{array}$ & $\begin{array}{l}\text { Stimulate osteoblast differentiation } \\
\text { through p38 MAPK and ERK signaling } \\
\text { pathways/saponin }\end{array}$ & {$[138]$} \\
\hline Caprifoliaceae & $\begin{array}{l}\text { Sambucus williamsii } \\
\text { Hance }\end{array}$ & $\begin{array}{l}\text { Stem and } \\
\text { ramulus }\end{array}$ & $\begin{array}{l}\text { Inflammation, bone } \\
\text { fractures, joint } \\
\text { diseases }\end{array}$ & $\begin{array}{l}\text { Suppress the OVX-induced increase in } \\
\text { bone turnover, inhibit bone resorption, } \\
\text { stimulate bone formation/lignans }\end{array}$ & {$[139]$} \\
\hline Compositae & $\begin{array}{l}\text { Carthamus tinctorius } \\
\text { L. }\end{array}$ & Seed & $\begin{array}{l}\text { Ankyloenteron, } \\
\text { rheumatism, and } \\
\text { chronic nephritis }\end{array}$ & $\begin{array}{l}\text { Prevent bone loss through modulation } \\
\text { ALP and IGF-1/lignans, flavones, } \\
\text { serotonins }\end{array}$ & {$[140,141]$} \\
\hline Compositae & $\begin{array}{l}\text { Silybum marianun } \\
\text { (L.) Gaertn }\end{array}$ & Seed & Liver disease & $\begin{array}{l}\text { Prevent bone loss in rats induced by OVX } \\
\text { with mild proliferative effects in } \\
\text { uterus/silibinin, isosilibinin, silydianin } \\
\text { and silychristin }\end{array}$ & {$[142,143]$} \\
\hline
\end{tabular}


Table 1: Continued.

\begin{tabular}{|c|c|c|c|c|c|}
\hline Family & Scientific name & $\begin{array}{l}\text { Plant parts } \\
\text { used }\end{array}$ & $\begin{array}{l}\text { Reported relevant } \\
\text { ethnomedical uses }\end{array}$ & $\begin{array}{l}\text { Pharmacological study/chemical } \\
\text { constituents }\end{array}$ & Reference \\
\hline Compositae & $\begin{array}{l}\text { Wedelia calendulacea } \\
\text { Less. }\end{array}$ & Flower & $\begin{array}{l}\text { Liver disorders, } \\
\text { jaundice, uterine } \\
\text { hemorrhage, } \\
\text { menorrhagia }\end{array}$ & $\begin{array}{l}\text { Promote bone formation, decrease bone } \\
\text { loss/isoflavones and wedelolactone }\end{array}$ & {$[144]$} \\
\hline Compositae & $\begin{array}{l}\text { Artemisia iwayomogi } \\
\text { Kitamura }\end{array}$ & $\begin{array}{l}\text { Aerial } \\
\text { parts }\end{array}$ & Diabetes and hepatitis & $\begin{array}{l}\text { Stimulate bone formation/phenolic } \\
\text { compounds }\end{array}$ & [145] \\
\hline Convolvulaceae & $\begin{array}{l}\text { Cuscuta chinensis } \\
\text { Lam. }\end{array}$ & Seed & $\begin{array}{l}\text { Sexual dysfunction, } \\
\text { osteoporosis, } \\
\text { senescence }\end{array}$ & $\begin{array}{l}\text { Enhance osteoblast differentiation and } \\
\text { mineralization/quercetin, kaempferol, } \\
\text { isorhamnetin, hyperoside and astragalin }\end{array}$ & {$[146,147]$} \\
\hline Davalliaceae & $\begin{array}{l}\text { Davallia formosana } \\
\text { Hayata }\end{array}$ & Rhizome & $\begin{array}{l}\text { Bone disease, } \\
\text { osteoporosis }\end{array}$ & $\begin{array}{l}\text { Prevent bone loss, enhance bone strength, } \\
\text { inhibit the deterioration of trabecular } \\
\text { microarchitecture via inhibition of bone } \\
\text { resorption/ }(-) \text {-epicatechin } \\
3 \text {-O- } \beta \text {-D-allopyranoside }\end{array}$ & {$[148]$} \\
\hline Dicksoniaceae & $\begin{array}{l}\text { Cibotium barometz } \\
\text { (L.) J. Sm. }\end{array}$ & Rhizome & $\begin{array}{l}\text { Lumbago, } \\
\text { rheumatism, } \\
\text { polyuria, leucorrhoea }\end{array}$ & $\begin{array}{l}\text { Prevent bone loss induced by } \\
\text { ovariectomy, inhibit osteoclast formation }\end{array}$ & {$[149]$} \\
\hline Dioscoreaceae & Dioscorea alata L. & Rhizome & $\begin{array}{l}\text { Dyspnea, } \\
\text { spermatorrhea, } \\
\text { leucorrhagia, diabetes }\end{array}$ & $\begin{array}{l}\text { Increase bone formation by inducing } \\
\text { mesenchymal stem cells differentiation } \\
\text { into osteoblasts }\end{array}$ & {$[150]$} \\
\hline Dioscoreaceae & $\begin{array}{l}\text { Dioscorea spongiosa J. } \\
\text { Q. Xi et al. }\end{array}$ & Rhizome & $\begin{array}{l}\text { Rheumatoid arthritis, } \\
\text { bone disorder }\end{array}$ & $\begin{array}{l}\text { Inhibit the decrease in bone mineral } \\
\text { density, stimulate proliferation and } \\
\text { mineralization of osteoblast, inhibit } \\
\text { formation and bone resorption of } \\
\text { osteoclast/seroidal saponins }\end{array}$ & {$[151,152]$} \\
\hline Dipsacaceae & $\begin{array}{l}\text { Dipsacus asperoides C. } \\
\text { Y. Cheng et T. M. Ai }\end{array}$ & Root & $\begin{array}{l}\text { Traumatic } \\
\text { ecchymoma, injury of } \\
\text { muscles, bone } \\
\text { fractures }\end{array}$ & $\begin{array}{l}\text { Inhibit bone loss induced by ovariectomy, } \\
\text { enhance osteoblast maturation and } \\
\text { differentiation by increasing BMP-2 } \\
\text { synthesis and activating p } 38 \text { and } \\
\text { ERK1/2/asperosaponin VI }\end{array}$ & {$[108,153]$} \\
\hline Ericaceae & $\begin{array}{l}\text { Vaccinium } \\
\text { angustifolium Aiton }\end{array}$ & Fruit & $\begin{array}{l}\text { Cardiovascular } \\
\text { disease }\end{array}$ & $\begin{array}{l}\text { Prevent bone loss in ovarian hormone } \\
\text { deficiency, stimulate osteoblast } \\
\text { differentiation and reduce mesenchymal } \\
\text { stromal cell senescence/phenolic acids } \\
\text { (gallic acid, p-hydroxybenzoic acid, } \\
\text { chlorogenic, p-coumaric, caffeic, ferulic } \\
\text { and ellagic acids), flavonoids } \\
\text { (anthocyanins, catechin, epichatechin, } \\
\text { quercetin, kaempferol and myrecetin) }\end{array}$ & {$[154]$} \\
\hline Eucommiaceae & $\begin{array}{l}\text { Eucommia ulmoides } \\
\text { Oliv. }\end{array}$ & Bark & $\begin{array}{l}\text { Hypertension, renal } \\
\text { injury }\end{array}$ & $\begin{array}{l}\text { Prevent estrogen deficiency-induced } \\
\text { bone loss, increase osteoblast } \\
\text { proliferation and inhibit differentiation } \\
\text { of osteoclast/lignans, iridoids, flavonoids } \\
\text { and terpenoids }\end{array}$ & [155-157] \\
\hline Euphorbiaceae & $\begin{array}{l}\text { Emblica officinalis } \\
\text { Gaertn. }\end{array}$ & Fruit & $\begin{array}{l}\text { Dyslipidemia, } \\
\text { atherosclerosis }\end{array}$ & $\begin{array}{l}\text { Induce osteoclast apoptosis through } \\
\text { downregulating the expression of IL- } 6 \\
\text { and NF- } \kappa B\end{array}$ & {$[158]$} \\
\hline Fabaceae & $\begin{array}{l}\text { Erythrina variegata } \\
\text { Linn }\end{array}$ & Stem bark & $\begin{array}{l}\text { Stomachache, } \\
\text { rheumatism, eye } \\
\text { ailments, swellings }\end{array}$ & $\begin{array}{l}\text { Suppress the bone loss by inhibiting } \\
\text { osteoclast differentiation and } \\
\text { maturation/genistein derivatives }\end{array}$ & {$[159,160]$} \\
\hline Fabaceae & $\begin{array}{l}\text { Glycine max (Linn.) } \\
\text { Merr. }\end{array}$ & Seed & $\begin{array}{l}\text { Cardiovascular } \\
\text { disease, cancer, } \\
\text { osteoporosis, renal } \\
\text { function }\end{array}$ & See section 3.1 .2 & {$[27-33]$} \\
\hline Fabaceae & $\begin{array}{l}\text { Onobrychis ebenoides } \\
\text { Boiss. et Spruner }\end{array}$ & $\begin{array}{l}\text { Whole } \\
\text { plant }\end{array}$ & Estrogenic activity & $\begin{array}{l}\text { Decrease bone loss without affecting } \\
\text { body and uterine weight/isoflavones } \\
\text { (ebenosin, afrormosin, formononetin } \\
\text { and daidzein), benzofurans and } \\
\text { benzoypyrans (ebenfuran I, ebenfuran II } \\
\text { and ebenfuran III ) }\end{array}$ & {$[161-163]$} \\
\hline
\end{tabular}


Table 1: Continued.

\begin{tabular}{|c|c|c|c|c|c|}
\hline Family & Scientific name & $\begin{array}{l}\text { Plant parts } \\
\text { used }\end{array}$ & $\begin{array}{l}\text { Reported relevant } \\
\text { ethnomedical uses }\end{array}$ & $\begin{array}{l}\text { Pharmacological study/chemical } \\
\text { constituents }\end{array}$ & Reference \\
\hline Fabaceae & Psoralea corylifolia $\mathrm{L}$. & Fruit & $\begin{array}{l}\text { Bone fracture, } \\
\text { osteomalacia and } \\
\text { osteoporosis }\end{array}$ & See section 3.1 .3 & [34-37] \\
\hline Fabaceae & $\begin{array}{l}\text { Pueraria lobate } \\
\text { (Willd.) Ohwi }\end{array}$ & Root & $\begin{array}{l}\text { Influenza, } \\
\text { hypertension, angina } \\
\text { pectoris }\end{array}$ & See section 3.1.4 & {$[38-41]$} \\
\hline Fabaceae & $\begin{array}{l}\text { Pueraria mirifica Airy } \\
\text { Shaw et } \\
\text { Suvatabandhu }\end{array}$ & Root & $\begin{array}{l}\text { Reproductive organs, } \\
\text { cardiovascular } \\
\text { diseases, climacteric } \\
\text { related symptoms }\end{array}$ & See section 3.1 .4 & {$[42,43]$} \\
\hline Fabaceae & $\begin{array}{l}\text { Rhynchosia volubilis } \\
\text { Lour. }\end{array}$ & Seed & $\begin{array}{l}\text { Toothache, rheumatic } \\
\text { arthritis, snake bite }\end{array}$ & $\begin{array}{l}\text { Facilitate osteoblastic MG- } 63 \text { cell } \\
\text { proliferation/genistein and daidzein }\end{array}$ & {$[164]$} \\
\hline Fabaceae & Sophora japonica L. & Fruit & $\begin{array}{l}\text { Hematochezia, } \\
\text { bleeding hemorrhoids }\end{array}$ & $\begin{array}{l}\text { Suppress formation and differentiation of } \\
\text { osteoclast/isoflavonoids }\end{array}$ & {$[165,166]$} \\
\hline Fabaceae & $\begin{array}{l}\text { Butea monosperma } \\
\text { (L.) Kuntze }\end{array}$ & Stem bark & Bone fracture & $\begin{array}{l}\text { Prevent OVX-induced bone loss by } \\
\text { stimulating bone } \\
\text { formation/methoxyisoflavones (cajanin, } \\
\text { isoformononetin, cladrin and } \\
\text { medicarpin) }\end{array}$ & {$[167]$} \\
\hline Fabaceae & Phaseolus vulgaris $\mathrm{L}$ & Seed & Estrogenic activity & $\begin{array}{l}\text { Prevent estrogen deficiency-induced } \\
\text { osteopenia without affecting the uterine } \\
\text { mass }\end{array}$ & {$[168]$} \\
\hline Fabaceae & Trifolium pratense L. & $\begin{array}{c}\text { Aerial } \\
\text { parts }\end{array}$ & $\begin{array}{l}\text { Menopause } \\
\text { symptoms, } \\
\text { cardiovascular disease }\end{array}$ & See section 3.1 .5 & {$[44-47]$} \\
\hline Ginkgoaceae & Ginkgo biloba Linn. & Leaf & $\begin{array}{l}\text { Cardiovascular } \\
\text { disease }\end{array}$ & $\begin{array}{l}\text { Reverse bone loss in } \\
\text { glucocorticoid-induced osteoporosis and } \\
\text { mandibular osteoporosis/kaempferol, } \\
\text { quercetin, isorhamnetin, and terpenoids } \\
\text { (ginkgolides and bilobalides) }\end{array}$ & {$[169,170]$} \\
\hline Juglandaceae & Juglans regia $\mathrm{L}$. & Fuit & $\begin{array}{l}\text { Heart disease, } \\
\text { prostate cancer, } \\
\text { hyperlipidemic }\end{array}$ & $\begin{array}{l}\text { Induce nodule formation of } \\
\text { osteoblast/ellagic acid, } \alpha \text {-tocopherol, fatty } \\
\text { acids, flavonoids and phenolic acids }\end{array}$ & {$[171]$} \\
\hline Labiatae & $\begin{array}{l}\text { Ajuga decumbens } \\
\text { Thunb. }\end{array}$ & $\begin{array}{l}\text { Whole } \\
\text { plant }\end{array}$ & $\begin{array}{l}\text { Hypertension, } \\
\text { hemoptysis, } \\
\text { carbuncles and joint } \\
\text { pain }\end{array}$ & $\begin{array}{l}\text { Downregulate the differentiation of } \\
\text { osteoclast, upregulate mineralization of } \\
\text { osteoblast-like MC3T3-E1 cells }\end{array}$ & {$[172]$} \\
\hline Labiatae & $\begin{array}{l}\text { Salvia miltiorrhiza } \\
\text { Bge }\end{array}$ & Root & $\begin{array}{l}\text { Cardiovascular } \\
\text { diseases }\end{array}$ & See section 3.1.6 & {$[48-52]$} \\
\hline Lauraceae & $\begin{array}{l}\text { Cinnamomum cassia } \\
\text { (L.) C. Presl }\end{array}$ & Bark & $\begin{array}{l}\text { Dyspepsia, gastritis, } \\
\text { blood circulation } \\
\text { disturbances, } \\
\text { inflammatory diseases }\end{array}$ & $\begin{array}{l}\text { Stimulate bone formation in vitro and } \\
\text { may contribute to the prevention of } \\
\text { osteoporosis and inflammatory bone } \\
\text { diseases/cinnamic aldehyde, cinnamic } \\
\text { alcohol, cinnamic acid, and coumarin }\end{array}$ & {$[173]$} \\
\hline Liliaceae & Allium cepa L. & Bulb & $\begin{array}{l}\text { Insomnia, } \\
\text { hyperglycemic, } \\
\text { Hyperlipidemic }\end{array}$ & $\begin{array}{l}\text { Decrease the ovariectomy-induced bone } \\
\text { resorption via attenuation of } \\
\text { RANKL-induced ERK, p } 38 \text {, and NF- } \kappa \text { B } \\
\text { activation }\end{array}$ & {$[174]$} \\
\hline Liliaceae & Allium sativum $\mathrm{L}$. & Bulb & $\begin{array}{l}\text { Influenza, dysentery, } \\
\text { tuberculosis }\end{array}$ & $\begin{array}{l}\text { Prevent bone loss, reverse the low BMD } \\
\text { and low tensile strength caused by } \\
\text { ovariectomy/allicin, } \\
\text { allylmethyltrisulphide, diallyldisulphide, } \\
\text { ajoene, monoterpenes (citral, geraniol } \\
\text { and linalool), and flavonoids (quercetin } \\
\text { and rutin) }\end{array}$ & {$[175]$} \\
\hline Liliaceae & $\begin{array}{l}\text { Anemarrhena } \\
\text { asphodeloides Bge. }\end{array}$ & Rhizome & $\begin{array}{l}\text { Lung disease, fever, } \\
\text { diabetes and } \\
\text { constipation }\end{array}$ & $\begin{array}{l}\text { Prevent OVX-induced bone loss in rats } \\
\text { through the promotion of bone } \\
\text { formation but not the inhibition of bone } \\
\text { resorption/steroidal saponins }\end{array}$ & {$[176]$} \\
\hline
\end{tabular}


Table 1: Continued.

\begin{tabular}{|c|c|c|c|c|c|}
\hline Family & Scientific name & $\begin{array}{l}\text { Plant parts } \\
\text { used }\end{array}$ & $\begin{array}{l}\text { Reported relevant } \\
\text { ethnomedical uses }\end{array}$ & $\begin{array}{l}\text { Pharmacological study/chemical } \\
\text { constituents }\end{array}$ & Reference \\
\hline Liliaceae & $\begin{array}{l}\text { Polygonatum } \\
\text { sibiricum } \text { Red. }\end{array}$ & Rhizome & $\begin{array}{l}\text { Hypotension, } \\
\text { Hyperglycemic, } \\
\text { Hyperlipidemic }\end{array}$ & Prevent bone loss/polysaccharide & {$[177]$} \\
\hline Linaceae & $\begin{array}{l}\text { Linum usitatissimum } \\
\text { L. }\end{array}$ & Seed & $\begin{array}{l}\text { Postmenopausal } \\
\text { osteoporosis }\end{array}$ & See section 3.1 .7 & {$[53-56]$} \\
\hline Lythraceae & $\begin{array}{l}\text { Heimia myrtifolia } \\
\text { Cham. }\end{array}$ & Leaf & Osteoporosis & $\begin{array}{l}\text { Stimulate formation and mineralization } \\
\text { of osteoblastic cell lines HOS58 and } \\
\text { saos-2/vertine (cryogenine), lythrine, } \\
\text { lythridine, polyphenols }\end{array}$ & {$[178]$} \\
\hline Malvaceae & $\begin{array}{l}\text { Abelmoschus manihot } \\
\text { (L.) Medik. }\end{array}$ & Leaf & $\begin{array}{l}\text { Chronic } \\
\text { glomerulonephritis }\end{array}$ & $\begin{array}{l}\text { Reduce bone loss in conditions of } \\
\text { estrogen deficiency/calcium }\end{array}$ & {$[179]$} \\
\hline Menispermaceae & $\begin{array}{l}\text { Tinospora cordifolia } \\
\text { (Willd.) Miers }\end{array}$ & Stem & $\begin{array}{l}\text { Dyspepsia, fever, } \\
\text { urinary diseases }\end{array}$ & $\begin{array}{l}\text { Estrogenic activity, prevent bone loss in } \\
\text { ovariectomized rats/alkaloids, terpenoids, } \\
\text { glycosides, sterols, lactones and fatty acids }\end{array}$ & {$[180]$} \\
\hline Myrsinaceae & $\begin{array}{l}\text { Labisia pumila var. } \\
\text { alata (Scheff.) Mez. }\end{array}$ & Root & $\begin{array}{l}\text { Menstrual } \\
\text { irregularities, painful } \\
\text { menstruation }\end{array}$ & $\begin{array}{l}\text { Prevent the changes in bone biochemical } \\
\text { markers but failed to prevent the bone } \\
\text { calcium loss induced by ovariectomy/C15 } \\
\text { monoene resorcinols, phenolic } \\
\text { compounds, flavonoids }\end{array}$ & {$[181]$} \\
\hline Oleaceae & $\begin{array}{l}\text { Ligustrum lucidum } \\
\text { Ait. }\end{array}$ & Fruit & $\begin{array}{l}\text { Menopausal } \\
\text { problems, tinnitus, } \\
\text { rheumatic pains, } \\
\text { palpitations, } \\
\text { insomnia symptoms }\end{array}$ & $\begin{array}{l}\text { Improve bone properties in aged rats via } \\
\text { increasing osteoblast formation and } \\
\text { mineralization/oleanolic acid, ursolic } \\
\text { acid, acetyloleanolic acid }\end{array}$ & {$[182,183]$} \\
\hline Orchidaceae & $\begin{array}{l}\text { Anoectochilus } \\
\text { formosanus Hayata }\end{array}$ & $\begin{array}{l}\text { Whole } \\
\text { plants }\end{array}$ & $\begin{array}{l}\text { Lung disease, } \\
\text { pleurodynia, } \\
\text { abdominal pain, } \\
\text { fever, hypertension } \\
\text { and snake bites }\end{array}$ & $\begin{array}{l}\text { Suppress the bone loss caused by estrogen } \\
\text { deficiency through suppression of } \\
\text { RANKL expression required for } \\
\text { osteoclast formation. }\end{array}$ & {$[184]$} \\
\hline Orobanchaceae & $\begin{array}{l}\text { Cistanche deserticola } \\
\text { Y. C. Ma }\end{array}$ & Stem & $\begin{array}{l}\text { Forgetfulness, loss of } \\
\text { hearing, chronic } \\
\text { constipation. }\end{array}$ & $\begin{array}{l}\text { Enhanced bone mineral density and bone } \\
\text { mineral content/harmine }\end{array}$ & {$[101]$} \\
\hline Orobanchaceae & $\begin{array}{l}\text { Cistanche salsa (C. A. } \\
\text { Mey.) G. Beck }\end{array}$ & Stem & $\begin{array}{l}\text { Kidney deficiency, } \\
\text { neurasthenia }\end{array}$ & $\begin{array}{l}\text { Suppress bone loss in ovariectomized } \\
\text { mice/(2E, 6R)-8-hydroxy-2, } \\
\text { 6-dimethyl-2-octenoic acid }\end{array}$ & {$[185]$} \\
\hline Pleurotaceae & $\begin{array}{l}\text { Pleurotus eryngii (De } \\
\text { Candolle: Fr.) Quel. }\end{array}$ & $\begin{array}{l}\text { Fruiting } \\
\text { body }\end{array}$ & $\begin{array}{l}\text { Liver, kidney and } \\
\text { gastrointestinal } \\
\text { disorders }\end{array}$ & $\begin{array}{l}\text { Alleviate the decrease in the trabecular } \\
\text { bond mineral density in ovariectomized } \\
\text { rats, increase the ALP activity and } \\
\text { secretion of osteoprotegerin, improve the } \\
\text { osteocalcin mRNA and Runx } 2 \text { gene } \\
\text { expression in osteoblasts; } \\
\text { Decrease the number of tartrate-resistant } \\
\text { acid phosphatase (TRAP)-positive } \\
\text { multinucleated cells and resorption areas } \\
\text { of osteoclast }\end{array}$ & {$[186]$} \\
\hline Polypodiaceae & $\begin{array}{l}\text { Drynaria fortunei } \\
\text { (Kunze) J. Sm. }\end{array}$ & Rhizome & $\begin{array}{l}\text { Bone fractures and } \\
\text { joint diseases }\end{array}$ & See section 3.1 .8 & {$[57-61]$} \\
\hline Punicaceae & $\begin{array}{l}\text { Punica granatum } \\
\text { Linn. }\end{array}$ & Fruit & $\begin{array}{l}\text { Parasitic infections, } \\
\text { ulcers, diarrhea, } \\
\text { dysentery, } \\
\text { hemorrhage, } \\
\text { respiratory } \\
\text { pathologies }\end{array}$ & $\begin{array}{l}\text { Increase bone volume and trabecular } \\
\text { number, and decrease trabecular } \\
\text { separation in OVX rats/genistein, } \\
\text { daidzein, ellagitannins and ellagic acid }\end{array}$ & {$[187]$} \\
\hline Ranunculaceae & Cimicifuga foetida $\mathrm{L}$. & Rhizome & $\begin{array}{l}\text { Cooling and } \\
\text { detoxification agent }\end{array}$ & $\begin{array}{l}\text { Inhibit osteoclastic bone resorption, } \\
\text { increase BMD in OVX mice/oxidized } \\
\text { cycloartane-type triterpenoids and } \\
\text { phenol type derivatives }\end{array}$ & {$[188]$} \\
\hline Ranunculaceae & $\begin{array}{l}\text { Cimicifuga racemosa } \\
\text { (L.) Nuttall }\end{array}$ & Rhizome & $\begin{array}{l}\text { Dysmenorrhea, labor } \\
\text { pains, menopausal } \\
\text { symptoms }\end{array}$ & See section 3.1 .9 & {$[62-66]$} \\
\hline
\end{tabular}


Table 1: Continued.

\begin{tabular}{|c|c|c|c|c|c|}
\hline Family & Scientific name & $\begin{array}{l}\text { Plant parts } \\
\text { used }\end{array}$ & $\begin{array}{l}\text { Reported relevant } \\
\text { ethnomedical uses }\end{array}$ & $\begin{array}{l}\text { Pharmacological study/chemical } \\
\text { constituents }\end{array}$ & Reference \\
\hline Rosaceae & $\begin{array}{l}\text { Prunus mume Sieb et } \\
\text { ZUCC. }\end{array}$ & Fruit & Chronic gastritis & $\begin{array}{l}\text { Increase alkaline phosphatase activity, cell } \\
\text { proliferation and mineralization, enhance } \\
\text { the expression of BMP-2 of } \\
\text { osteoblast/citric acid, malic acid, } \\
\text { chlorogenic acid and } \\
\text { 5-hydroxymethy-furfural }\end{array}$ & {$[189,190]$} \\
\hline Rosaceae & Rubus coreanus Miq. & Fruit & $\begin{array}{l}\text { Impotence, } \\
\text { spermatorrhoea, and } \\
\text { back pain }\end{array}$ & $\begin{array}{l}\text { Prevent bone loss caused by estrogen } \\
\text { deficiency by dual regulation of the } \\
\text { enhancement of osteoblast function and } \\
\text { induction of osteoclast apoptosis/ellagic } \\
\text { acid, fupenzic acid, } \beta \text {-sitosterol }\end{array}$ & {$[191,192]$} \\
\hline Rubiaceae & $\begin{array}{l}\text { Morinda officinalis } \\
\text { How }\end{array}$ & Root & Rheumatism & See Section 3.1 .10 & {$[67-71]$} \\
\hline Rutaceae & $\begin{array}{l}\text { Poncirus trifoliata (L.) } \\
\text { Raf. }\end{array}$ & Fruit & $\begin{array}{l}\text { Gastritis, dysentery, } \\
\text { digestive tract ulcers, } \\
\text { uterine contraction, } \\
\text { and cardiovascular } \\
\text { diseases }\end{array}$ & $\begin{array}{l}\text { Inhibit glucocorticoid-induced bone loss } \\
\text { by decreasing expression of } \\
\text { anxA6/flavone (poncirin, hesperidin, } \\
\text { rhoifolin, naringin, neohesperidin) }\end{array}$ & [193] \\
\hline Rutaceae & Citrus paradisi Macf. & Fruit & $\begin{array}{l}\text { Digestion system, lose } \\
\text { weight }\end{array}$ & $\begin{array}{l}\text { Improve bone quality by enhancing bone } \\
\text { mineral deposition in ORX rats/vitamin } \\
\mathrm{C} \text {, hesperidin and limonoids }\end{array}$ & {$[194,195]$} \\
\hline Scrophulariaceae & $\begin{array}{l}\text { Rehmannia glutinosa } \\
\text { Libosch }\end{array}$ & Root & $\begin{array}{l}\text { Haemostatic, } \\
\text { cardiotonic, and } \\
\text { diuretic agent }\end{array}$ & $\begin{array}{l}\text { Increase ALP activity and the expression } \\
\text { of the OPG of osteoblast, decrease the } \\
\text { number of TRAP-positive MNCs and the } \\
\text { resorption areas of osteoclast, alleviate } \\
\text { the decrease in the trabecular BMD, and } \\
\text { increase the cortical bone thickness } \\
\text { ovariectomy-induced osteoporotic } \\
\text { rats/luteolin, mannitol, stigmasterol, } \\
\text { campesterol, catalpol, rehmannin. }\end{array}$ & [196] \\
\hline Solanaceae & $\begin{array}{l}\text { Withania somnifera } \\
\text { Dunn. }\end{array}$ & Root & $\begin{array}{l}\text { Nerve diseases and } \\
\text { anxiety }\end{array}$ & $\begin{array}{l}\text { Inhibit bone loss in ovariectomized } \\
\text { rats/withanolides }\end{array}$ & {$[197]$} \\
\hline Taxaceae & $\begin{array}{l}\text { Taxus yunnanensis } \\
\text { cheng et L.K. }\end{array}$ & $\begin{array}{l}\text { Seed, } \\
\text { bark }\end{array}$ & Cancer & $\begin{array}{l}\text { Increase bone mineral content and bone } \\
\text { mineral density in ovariectomized } \\
\text { rats/isotaxiresinol, taxol, harringtonine }\end{array}$ & {$[90]$} \\
\hline Theaceae & $\begin{array}{l}\text { Stewartia koreana } \\
\text { Nakai ex Rehd. }\end{array}$ & Leaf & $\begin{array}{l}\text { Inflammatory } \\
\text { diseases }\end{array}$ & $\begin{array}{l}\text { Inhibit osteoclast differentiation and } \\
\text { prevent inflammatory bone } \\
\text { loss/spinasterol glycoside }\end{array}$ & [198] \\
\hline Ulmaceae & $\begin{array}{l}\text { Ulmus davidiana } \\
\text { Planch. }\end{array}$ & Bark & $\begin{array}{l}\text { Oedema, mastitis, } \\
\text { gastric cancer and } \\
\text { inflammation }\end{array}$ & $\begin{array}{l}\text { Promote osteoblastic differentiation by } \\
\text { increasing bone morphogenic protein- } 2 \\
\text { as well as ALP mRNA expression in } \\
\text { MC3T3-E1 cells, inhibit bone } \\
\text { resorption/davidianones A, B, and C, } \\
\text { mansonones E, F, H, and I }\end{array}$ & [199] \\
\hline Ulmaceae & $\begin{array}{l}\text { Ulmus wallichiana } \\
\text { Planch. }\end{array}$ & Bark & Bone fracture & $\begin{array}{l}\text { Mitigate ovariectomy-induced } \\
\text { osteoporosis in rats, stimulate osteoblast } \\
\text { function and inhibit osteoclast } \\
\text { differentiation/quercetin- } 6 \text {-C- } \beta \text {-D- } \\
\text { glucopyranoside }\end{array}$ & [200-203] \\
\hline Verbenaceae & Vitex agnus-castus L. & Fruit & $\begin{array}{l}\text { Premenstrual } \\
\text { symptoms, } \\
\text { climacteric } \\
\text { complaints }\end{array}$ & $\begin{array}{l}\text { Protect bone in orchidectomized } \\
\text { rats/apigenin, cascitin, and dopaminergic } \\
\text { compounds }\end{array}$ & {$[204]$} \\
\hline Vitaceae & $\begin{array}{l}\text { Cissus quadrangularis } \\
\text { L. }\end{array}$ & $\begin{array}{l}\text { Aerial } \\
\text { parts, } \\
\text { root }\end{array}$ & $\begin{array}{l}\text { Hemorrhoids, } \\
\text { menstrual disorders, } \\
\text { scurvy, flatulence, } \\
\text { bone fractures, bone } \\
\text { diseases }\end{array}$ & $\begin{array}{l}\text { Prevent bone loss in ovariectomized rats, } \\
\text { stimulate osteoblastogenesis through } \\
\text { up-regulation of MAPK-dependent } \\
\text { alkaline phosphatase activity/ } \beta \text {-sitosterol, } \\
\delta \text {-amyrin, } \delta \text {-amyrone, favanoids } \\
\text { (quercetin), } \\
6^{\prime} \text {-O-trans-cinnamoyl-catalpol }\end{array}$ & [205-207] \\
\hline
\end{tabular}


TABle 1: Continued.

\begin{tabular}{llcll}
\hline Family & Scientific name & $\begin{array}{c}\text { Plant parts } \\
\text { used }\end{array}$ & $\begin{array}{l}\text { Reported relevant } \\
\text { ethnomedical uses }\end{array}$ & $\begin{array}{l}\text { Pharmacological study/chemical } \\
\text { constituents }\end{array}$ \\
\hline Zingiberaceae & $\begin{array}{l}\text { Curcuma comosa } \\
\text { Roxb. }\end{array}$ & Rhizome & $\begin{array}{l}\text { Postpartum, uterine } \\
\text { bleeding, } \\
\text { inflammation }\end{array}$ & $\begin{array}{l}\text { Prevent bone loss induced by estrogen } \\
\text { deficiency/diarylheptanoids, curcumin }\end{array} \quad$ [208, 209] \\
\hline
\end{tabular}

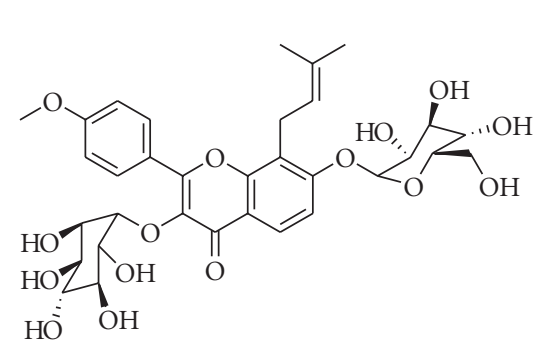

Icariin

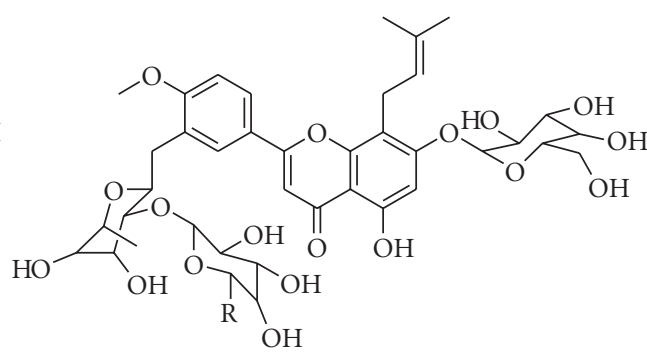

$\mathrm{R}=\mathrm{H} \quad$ Epimedin $\mathrm{B}$

$\mathrm{R}=\mathrm{CH}_{3} \quad$ Epimedin $\mathrm{C}$<smiles>CC(C)=CCc1c(O)cc(O)c2c(=O)c(OC(O)C(O)O)c(-c3ccc(O)cc3)oc12</smiles>

Ikarisoside A

Figure 1: Chemical structure of compounds from Epimedium plants.

women and have a role in the prevention and treatment of postmenopausal osteoporosis [27]. Epidemiological studies and clinical trials suggest that soy isoflavones have beneficial effects on bone mineral density, bone turnover markers, and bone mechanical strength in postmenopausal women. The diet containing $22 \%$ soybean protein can be just as effective as daily estrogen administration in suppressing bone loss induced by ovariectomy. However, unlike estrogen, a soybean protein diet does not have uterotrophic side effects, and does not decrease the markers of bone turnover. The modulation of soybean protein and flavonoids on nuclear receptors focuses especially on the expression of receptors for estrogens, progesterone, androgen, vitamin D, retinoic acid, and thyroid hormones as well as the potential impact on physiological functions [28]. Soy flavonoids can modulate trabecular microstructural properties, inhibit bone loss in both osteoporotic animal models and postmenopausal women by regulating bone metabolism-related gene expression, including calciotropic receptor, cytokines, growth factors, ALP, collagen type I (COL I), and osteocalcin. In addition, soy flavonoids, phytoestrogen, in chemical structure, are antiestrogenic on both ER alpha and ER beta-dependent gene expression in the brain and estrogendependent behavior $[29,30]$.

Genistein (Figure 2) exhibits estrogenic action in bone and bone marrow to regulate B-lymphopoiesis and prevent bone loss without exhibiting estrogenic action in the uterus. The mechanism through which flavonoids may exert antiosteoporotic effects seems to depend, at least in part, on their mixed estrogen agonist-antagonist properties. An alternative hypothetical mechanism could derive from other biochemical actions of flavonoids such as inhibition of enzymatic activity, in particular protein kinases, or activation of an "orphan" receptor distinct from the estrogen type I receptor [31]. The results from intervention studies are still controversial. One of the potential reasons for these inconsistencies could be due to the individual differences in the flavonoids metabolism. Recently, it has been suggested that the clinical effectiveness of flavonoids might partly depend on the ability to produce equol, a gut bacterial metabolite of daidzein showing stronger estrogenic activity than the predominant flavonoids $[32,33]$.

3.1.3. Psoralea corylifolia L. Psoralea corylifolia L. belongs to Fabaceae, the fruit is one of the commonly used herbs in formulas that are prescribed for the treatment of fractures, bone and joint diseases. Recent research suggests that $P$. corylifolia has potent oestrogenic effects and that its fruits may be a useful remedy for bone fractures, osteomalacia and osteoporosis [34]. The extract of P. corylifolia fruits cannot only significantly increase the concentration of inorganic phosphorus in serum, but also evidently promote bone calcification in rats. Both the extracts of its fruits and seeds and two isoflavones (corylin and bavachin, Figure 3) isolated from this plant can stimulate bone formation and have potential antiosteoporotic activity [35]. Bavachalcone (Figure 3) inhibits osteoclastogenesis by interfering with the ERK and Akt signaling pathways and the induction of c-Fos and NFATc1 during differentiation. Components derived from P. corylifolia, including bakuchiol, corylin, psoralidin, and isobavachin (Figure 3 ), have strong antioxidant activities, and corylin and bavachin have been shown to stimulate osteoblastic proliferation. Bakuchiol has a threefold higher binding affinity for ER $\alpha$ than for ER $\beta$. Bakuchiol and extracts treatments had no uterotrophic activity even though they demonstrated oestrogenic activity in the in vitro assays, and reduced postmenopausal bone loss by increasing ALP, Ca concentrations, serum $\mathrm{E}_{2}$ concentration, and bone mineral density [36]. Psoralen (Figure 3), a coumarin-like derivative extracted from fruits of $P$. corylifolia L., has been 
<smiles>[R]c1ccc(-c2coc3cc(O)cc([R])c3c2=O)cc1</smiles>

$\begin{array}{lll} & \mathrm{R}_{1} & \mathrm{R}_{2} \\ \text { Genistein } & \mathrm{OH} & \mathrm{OH} \\ \text { Daidzein } & \mathrm{H} & \mathrm{OH} \\ \text { Biochanin A } & \mathrm{OH} & \mathrm{OCH}_{3}\end{array}$

FIgURE 2: Chemical structure of compounds from Glycine max L.<smiles>COc1cc(O)c(C(=O)/C=C/c2ccc(O)cc2)cc1CC=C(C)C</smiles>
Corylin Bavachin Bavachalcone Isobavachin<smiles>[R]Oc1ccc(/C=C/[C@@](C)(C=C)CC/C=C/CC)cc1</smiles>

Figure 3: Chemical structure of compounds from Psoralea corylifolia L.

reported to posses stimulatory effect on local new bone formation in vivo, and promote osteoblast differentiation in primary mouse calvarial osteoblasts in a dose-dependent manner by upregulation of expressions of osteoblast-specific marker genes including type I collagen, osteocalcin and bone sialoprotein and enhancement of ALP activity. It also upregulates the expression of BMP- 2 and BMP-4 genes, increases the protein level of phospho-Smad1/5/8, and activates BMP reporter (12xSBE-OC-Luc) activity in a dosedependent manner, as well as enhancing the expression of Osx, the direct target gene of BMP signaling. This suggests that psoralen acts through the activation of BMP signaling to promote osteoblast differentiation and demonstrates that psoralen could be a potential anabolic agent to treat patients with bone loss-associated diseases such as osteoporosis [37].

3.1.4. Pueraria lobata (Willd.) Ohwi and P. mirifica Airy Shaw et Suvatabandhu. Pueraria lobata (Willd.) Ohwi is a wild creeper plant of family Fabaceae. Its root, which is one of the earliest and most important crude herbs used in Chinese medicine for various medicinal purposes has a high content of isoflavonoids such as daidzein and genistein (Figure 2). The root of P. lobata shows a preventive effect on bone loss by increasing the BMD (bone mineral density) and BMC (bone mineral content) in the rats and mice of ovariectomy and orchidectomy without exhibiting estrogenic action in the uterus [38-40]. Puerarin (Figure 4), a natural isoflavonoid found in P. lobata, caused a significant increase in cell viability, ALP activity and mineral nodules formation in osteoblasts through activation of the PI3K/Akt pathway [41].

In Thailand, another species of the genus Pueraria plant, P. mirifica Airy Shaw et Suvatabandhu has been thoroughly examined for its estrogenic effects on female reproductive organs, which exhibited a higher estrogenic activity on reproductive organs than that of $P$. lobata. The long-term administration of $P$. mirifica prolongs the menstrual cycle length, suppresses folliculogenesis and ovulation in adult female monkeys, and decreases serum luteinizing hormone and follicle stimulating hormone levels, indicating that $P$. mirifica has an estrogenic effect on female reproductive systems. Phytoestrogens found in P. mirifica can be categorized 
<smiles>[R3]c1cc([R3])c2c(c1[R])OCC(c1ccc(O)cc1)C2=O</smiles>

$\begin{array}{llll} & \mathrm{R}_{1} & \mathrm{R}_{2} & \mathrm{R}_{3} \\ \text { Genistin } & \mathrm{H} & \text { OGlu } & \mathrm{OH} \\ \text { Daidin } & \mathrm{H} & \text { OGlu } & \mathrm{H} \\ \text { Puerarin } & \mathrm{Glu} & \mathrm{H} & \mathrm{H} \\ \text { Mirificin } & \mathrm{Glu}(6)-(1) \text { Apiose } & \mathrm{H} & \mathrm{H}\end{array}$<smiles>O=c1oc2cc(O)ccc2c2oc3cc(O)ccc3c12</smiles><smiles></smiles>

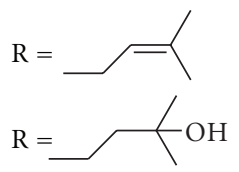

Kwakhurin<smiles>[R]c1c(C)c(O)cc(O)c1C1COc2cc(O)ccc2C1=O</smiles><smiles>CC1(C)C=Cc2cc3c(cc2O1)OC1c2ccc(O)cc2OCC31O</smiles>

Tuberosin

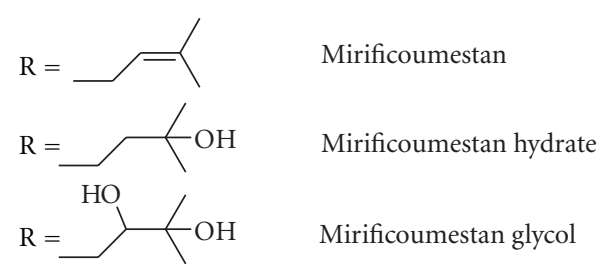

Coumestrol

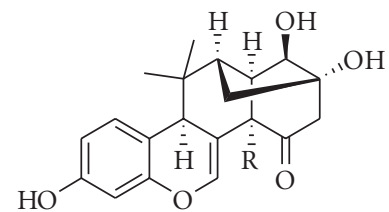

$\mathrm{R}=\mathrm{OH} \quad$ Miroestrol

$\mathrm{R}=\mathrm{H} \quad$ Deoxymiroestrol

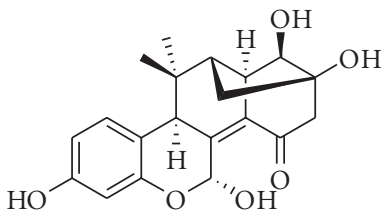

Iso-miroestrol<smiles>COc1c(O)cc2oc3c(c2c1CC=C(C)C)COc1cc(O)ccc1-3</smiles>

Puemiricarpene

Figure 4: Chemical structure of compounds from Pueraria lobata (Willd.) Ohwi and P. mirica Airy Shaw et Suvatabandhu.

into three groups as (i) ten isoflavonoids, comprised of daidzein, daidzin, genistin, genistein, kwakhurin, kwakhurin hydrate, tuberosin, puerarin, mirificin and puemiricarpene (Figure 4); (ii) four coumestrans, comprised of coumestrol, mirificoumestan, mirificoumestan glycol and mirificoumestan hydrate (Figure 4); and (iii) three chromenes, comprised of miroestrol, deoxymiroestrol, and isomiroestrol (Figure 4), which are rich in the plant and are known for preventing bone loss induced by estrogen deficiency [42]. P. mirifica dose-dependently prevents bone loss induced by orchidectomy and ovariectomy, and can be used a preventative medicine or as a therapeutic agent for the symptoms related to estrogen deficiency in menopausal women as well as in andropausal men [43].

3.1.5. Trifolium pratense L. Trifolium pratense (red clover) is one of the 250 species of the genus Trifolium belonging to Fabaceae. Red clover has been cultivated in Europe since the third or fourth century and contains four detectable estrogenic isoflavones: daidzein (Figure 2), genistein (Figure 2), formononetin (Figure 5), and biochanin A (Figure 2). Its isoflavones are effective in decreasing bone loss induced by ovariectomy, probably by reduction of the bone turnover via inhibition of bone resorption $[44,45]$. Daidzein can inhibit the proliferation and differentiation of osteoclasts; this is possibly due to increasing apoptosis of osteoclast progenitors mediated by ERs. The mechanism of action of isoflavones is evidently different from that of estrogens, which have a phytoestrogen-mediated stimulation in osteoblasts rather than an inhibition in osteoclasts $[46,47]$.

3.1.6. Salvia miltiorrhiza Bunge. Salvia miltiorrhiza Bunge (Labiatae), a traditional Chinese medicine, widely used in clinical practice for the prevention and treatment of cardiocerebral vascular diseases. Pharmacological testing showed that $S$. miltiorrhiza has anticoagulant, vasodilatory, increased blood flow, anti-inflammatory, free radical scavenging, mitochondrial protective activities. Phytochemical studies revealed multiple groups of compounds from S. miltiorrhiza Bunge extract, the main constituents of which include 
<smiles>COc1ccc(C2COc3cc(O)ccc3C2=O)cc1</smiles>

Formononetin

Figure 5: Chemical structure of formononetin.

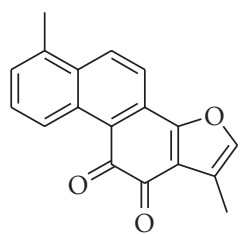

Tanshinone I<smiles>CC(=O)c1ccc(O)c(O)c1</smiles>

Protocatechuicaldehyde

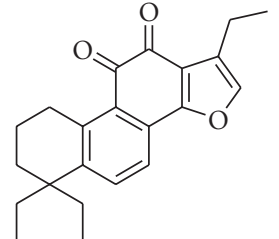

Tanshinone II A<smiles>O=C(O)C(O)Cc1ccc(O)c(O)c1</smiles>

Salvianolic acid A<smiles>CCC1COC2=C1C(=O)C(=O)c1c2ccc2c1CCCC2(CC)CC</smiles>

Cryptotanshinone

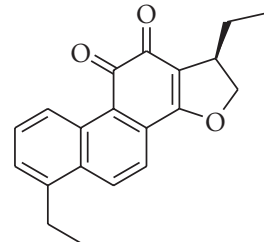

15,16-dihydrotanshinone I<smiles>O=C(/C=C/c1cccc2oc(-c3ccc(O)c(O)c3)c(C(=O)OC(Cc3ccc(O)c(O)c3)C(=O)O)c12)OC(Cc1ccc(O)c(O)c1)C(=O)O</smiles>

Salvianolic acid B

FIgURE 6: Chemical structure of compounds from Salvia miltiorrhiza Bunge.

tanshinones (tanshinone I, tanshinone IIA, cryptotanshinone, 15, 16-dihydrotanshinone I) and phenolics (protocatechuic aldehyde, salvianolic acid A, and salvianolic acid B) (Figure 6) [48]. S. miltirrhiza treatment significantly ameliorate the decrease in BMD and trabecular bone mass, decreases the TRAP activity and oxidative stress parameters including MDA (malondialdehyde) and $\mathrm{NO}$ (nitric oxide) induced by OVX in castrated male mice [49]. The tanshinones can reduce the formation of TRAPpositive multinuclear osteoclasts; Tanshinone IIA (Figure 6) can partially prevent ovariectomy-induced bone loss by suppressing bone turnover in vivo without stimulating osteoblast ALP activity, suppress osteoclast formation by inhibiting the expression of $\mathrm{c}$-fos and NFATc1 induced by RANKL [50]. Salvianolic acid A, the aqueous bioactive component from S. miltiorrhiza Bunge, effectively prevents bone loss from long-term administration of prednisone in rats, protects bone from glucocorticoid induced bone marrow impairment by stimulating osteogenesis and depressing adipogenesis in bone marrow stromal cells [51]. Salvianolic acid B, another aqueous bioactive component, prevents glucocorticoid induced cancellous bone loss and decreases adipogenesis. Salvianolic acid B stimulates bone marrow stromal cell (MSC) differentiation to osteoblast and increases osteoblast activities, whilst decreasing glucocorticoid associated adipogenic differentiation through regulating the mRNA expression of PPAR- $\gamma$, Runx2, Dickkopf-1, and $\beta$ catenin in MSC [52].

3.1.7. Linum usitatissimum L. Linum usitatissimum L. originally grows in Europe and warm areas of Asia, and is now widely cultivated in warm areas including America, Canada and North Europe. Its seed, also called linseed or flaxseed, can potentially exert positive effects on bone of postmenopausal women. Flaxseed is the richest source of lignans including enterodiol, enterolactone, secoisolariciresinol, and matairesinol (Figure 7), all of which are reported to have both weak estrogenic and anti-estrogenic activities [53]. Lignans are structurally similar to tamoxifen, which has beneficial effects on bone [54]. Flaxseed is also a rich source of polyunsaturated fatty acids (PUFA), especially $\alpha$-linolenic acid. Alpha-linolenic acid may decrease the rate of bone resorption by inhibiting the biosynthesis of prostaglandins. Lignans present in flaxseed may also possess antioxidant properties. Oxygen-derived free radicals, which are formed by a number of phagocytes including monocytes, macrophages, and neutrophils, have been reported to increase chronic inflammatory diseases, aging and osteoporosis. In vivo and in vitro findings indicate that free radicals generated in the bone environment enhance osteoclast formation and bone resorption. Hence, flaxseed may reduce the rapid rate of bone loss experienced by 
<smiles>OCC(CO)[C@H](CO)Cc1cccc(O)c1</smiles>

Enterodiol<smiles>O=C1OC[C@H](Cc2cccc(O)c2)[C@@H]1Cc1cccc(O)c1</smiles>

Enterolactone<smiles>COc1cc(C[C@@H](CO)[C@H](CO)Cc2ccc(O)c(OC)c2)ccc1O</smiles>

Secoisolariciresinol<smiles>COc1cc(C[C@H]2COC(=O)[C@@H]2Cc2ccc(O)c(OC)c2)ccc1O</smiles>

Matairesinol

FIGURE 7: Chemical structure of compounds from Linum usitatissimum L.<smiles>O=C1C[C@H](c2ccc(O)cc2)Oc2cc(CC3O[C@@H](O)[C@@H](O)[C@@H](O)[C@H](O)[C@H]3O)cc(O)c21</smiles>

Naringin<smiles>O=C1C[C@H](c2ccc(O)c(O)c2)OC2=CC(=CC(O)=C1O)OC1O[C@@H](CO)[C@@H](O)[C@H](O)[C@H](O)[C@H]1OCC[C@H]2O</smiles>

Neoeriocitrin

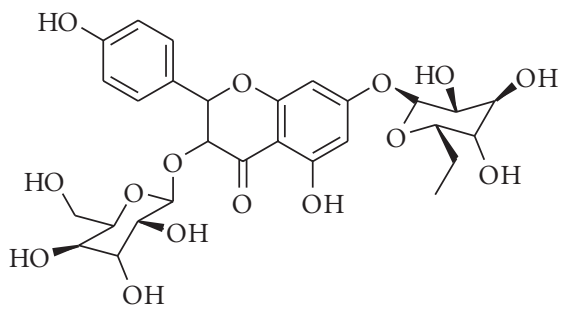

Kaempferol-3-O- $\beta$-D-glucopyranoside-7-O- $\alpha$-L-arabinofuranoside<smiles>O=C1C[C@H](c2ccc(O)cc2)Oc2cc(O)cc(O)c21</smiles>

Naringenin

Figure 8: Chemical structure of compounds from Drynaria fortunei (Kunze) J. Sm.

postmenopausal women, in part, by enhancing antioxidant status $[55,56]$.

3.1.8. Drynaria fortunei (Kunze) J. Sm. The rhizome of Drynaria fortunei (Kunze) J. Sm., family Polypodiaceae, has a long medicinal history in the eastern Asia and is effective for the treatment of inflammation, hyperlipemia, arteriosclerosis, and gynecological diseases such as osteoporosis. The traditional Chinese and Korean prescription drugs to treat osteoporosis usually contain the rhizome of Drynaria fortune. In recent study, it has been found that Drynaria fortune has therapeutic effects on osteoporosis and bone fracture in the ovariectomized rat model, and can enhance bone formation through induction of BMP-2 and ALP, accumulation of bone matrix proteins such as type I collagen, up-regulated Runx2 and osteocalcin expression [57]. The flavonoids in Drynaria rhizome, including naringin, neoeriocitrin, kaempferol-3-O- $\beta$-D-glucopyranoside-7-O- $\alpha$-Larabinofuranoside (Figure 8), are antiosteoporotic chemical constituents which can activate the estrogen receptors (ERs), and replace estrogen which can be of clinical use
[58]. Naringin (Figure 8) is the main active ingredients of drynariae flavonoids, which could inhibit the retinoic acidinduced osteoporosis in rats, increase BMP-2 expression and induce the bone formation, enhance the proliferation and osteogenic differentiation of human bone mesenchymal stem cells (BMSCs) in osteoporosis diseases [59, 60]. Naringin and its metabolite naringenin revealed a double directional adjusting function of estrogenic and anti-estrogenic activities primarily through selectively binding with ER, which could prevent and treat osteoporosis with the mechanism of estrogenic receptor agitation [61].

3.1.9. Cimicifuga racemosa (L.) Nuttall. Cimicifuga racemosa (Black cohosh), botanically a member of Ranunculaceae, has been widely used in native American therapy for a variety of ailments including dysmenorrheal and labor pains as well as for the treatment of menopausal symptoms. Black cohosh contains a number of compounds with potential bioactivity such as triterpene, glycosides, resin, salycilates, isoferulic acid, sterols, and alkaloids [62]. Black cohosh does not appear to alter the hormonal pattern associated 

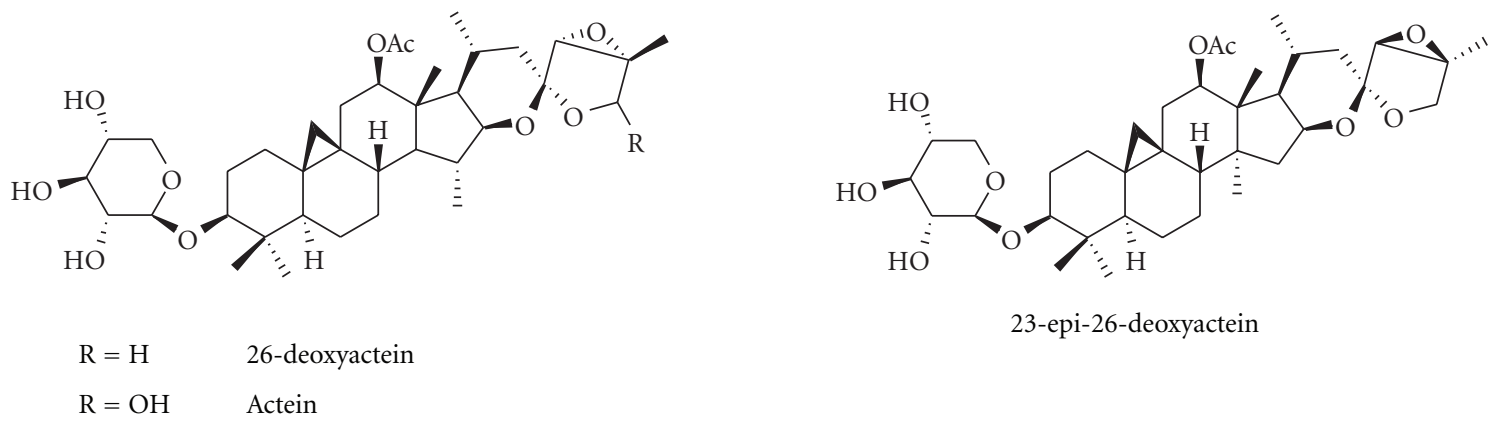

23-epi-26-deoxyactein

FIgURE 9: Chemical structure of compounds from Cimicifuga racemosa (L.) Nuttall.

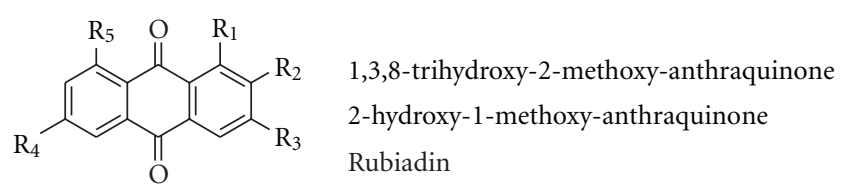

$\begin{array}{lllll}\mathrm{R}_{1} & \mathrm{R}_{2} & \mathrm{R}_{3} & \mathrm{R}_{4} & \mathrm{R}_{5} \\ \mathrm{OH} & \mathrm{OCH} 3 & \mathrm{OH} & \mathrm{H} & \mathrm{OH} \\ \mathrm{OCH}_{3} & \mathrm{OH} & \mathrm{H} & \mathrm{H} & \mathrm{H} \\ \mathrm{OH} & \mathrm{CH}_{3} & \mathrm{OH} & \mathrm{H} & \mathrm{H}\end{array}$

FIGURE 10: Chemical structure of compounds from Morinda officinalis How.

with menopause, lower estrogen accompanied by elevated luteinizing hormone (LH), and follicle-stimulating hormone $(\mathrm{FSH})$. Black cohosh results in a significant increase in trabecular bone mineral density of the proximal metaphysis of the tibia, enhances differentiation and increases the OPG-to-RANKL ratio of normal human osteoblasts [63]. Deoxyactein, including 26-deoxyactein, acetin, and 23-epi26-deoxyactein (Figure 9), active component from black cohosh causes a significant elevation of cell growth, alkaline phosphatase activity, collagen content, and mineralization in the cells. Moreover, deoxyactein significantly decreases the production of reactive oxygen species (ROS) and osteoclast differentiation-inducing factors such as TNF- $\alpha$, IL-6, and receptor activator of nuclear factor- $\kappa \mathrm{B}$ ligand in the presence of antimycin A $[64,65]$. In an ovariectomized rat model of osteoporosis, extracts of black cohosh decreased urinary excretion of cross-links; however, the positive effect on trabecular BMD and on bone quality as assessed by mechanical testing was weaker than that of raloxifene. In a similar study on orchidectomized rats, extracts of black cohosh mitigated bone loss at the tibial metaphysis after 3 months. The analysis of skeletal and uterine effects by black cohosh in an ovariectomized rat model revealed weak protective effects on bone loss and on reduction of serum levels of osteocalcin and cross-laps, but no increase in uterine weight. In a small randomized controlled trial of 62 women, black cohosh alleviated menopause symptoms without affecting endometrial thickness of the uterus. However, the supplementation with black cohosh did not exhibit positive effects in severe (senile) osteopenic fracture healing as seen in early osteoporosis in rats $[66]$.

3.1.10. Morinda officinalis How. Morinda officinalis How belongs to family of Rubiaceae and grows in the south of China. In Chinese traditional medicine, it has been used as a kidney tonic and for strengthening bones. In a sciatic neurectomized mice model, the root extracts significantly and dose-dependently suppressed the decrease in hind limb thickness, tibia failure load, BMD, tibia $\mathrm{Ca}$ and $\mathrm{P}$ contents with an increase in serum osteocalcin levels. In addition, the root extract also significantly and dose-dependently suppressed the decrease in histomorphometric parameters of the tibia such as volume, length and thickness of trabecular bone and thickness of cortical bone in ovariectomized rats. They may act as both a suppressor of bone resorption and an enhancer of bone formation in vivo and may have some favorable effects for preventing and treating the osteoporosis induced by sciatic neurectomy and ovariectomy $[67,68]$. The polysaccharides from Morinda officinalis can exert an increase in bone mineral density and mineral element concentration, a decrease in serum cytokines level in OVX rats [69]. The anthraquinones isolated from $M$. officinalis, have been proved to have inhibitory effects on osteoclastic bone resorption. 1,3,8-trihydroxy-2-methoxyanthraquinone, 2-hydroxy-1-methoxy-anthraquinone and rubiadin (Figure 10) decrease the formation of bone resorption pits, the number of multinucleated osteoclasts, and the activity of tartrate resistant acid phosphates (TRAP) and cathepsin $\mathrm{K}$ in the coculture system of osteoblasts and bone marrow cells in the presence of 1,25-dihydroxyvitamin D3 and dexamethasone. They also enhance the apoptosis of osteoclasts induced from bone marrow cells with M-CSF and RANKL. In addition, these compounds improve the ratio of OPG and RANKL in osteoblasts, interfere with the JNK and NF- $\kappa \mathrm{B}$ signal pathway, and reduce the expression of calcitonin receptor (CTR) and carbonic anhydrase/II (CA II) in osteoclasts induced from bone marrow cells with M-CSF and RANKL. These findings indicate that the anthraquinone compounds from $M$. officinalis are potential inhibitors of bone resorption, and may also serve as evidence to explain the mechanism of the inhibitory effects of some other reported anthraquinones on bone loss [70, 71]. 


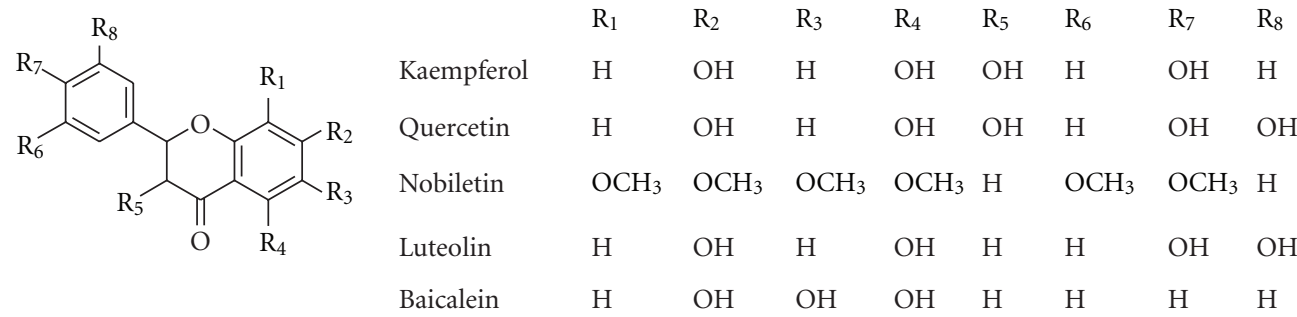<smiles>[R3]c1cc([C@H]2Oc3cc(O)cc(O)c3C[C@H]2OC(=O)c2cc(O)c(O)c(O)c2)cc(O)c1O</smiles><smiles>COc1cc(O)c(CC=C(C)C)c(O)c1C(=O)/C=C/c1ccc(O)cc1</smiles><smiles>COc1cc(O)c(CC=C(C)C)c(O)c1C(=O)/C=C/c1ccc(O)cc1</smiles><smiles>[R]c1cc([C@H]2Oc3cc(O)cc(O)c3C[C@H]2O)cc(O)c1O</smiles>

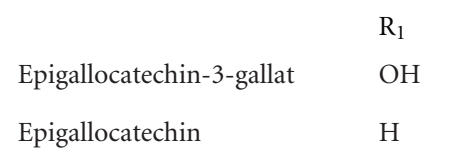

Xanthohumol

$\mathrm{R}_{1} \quad \mathrm{R}_{2}$ $\mathrm{R}_{1}$ Epigallocatechin $\mathrm{H}$

\section{Honokiol $\mathrm{OH} \quad \mathrm{H}$}

Magnolol $\mathrm{H} \quad \mathrm{OH}$ Epicatechin-3-gallate $\mathrm{OH}$ Epi-catechin $\mathrm{H}$<smiles>[R3]c1cc(O)c2c(c1)OC(c1ccc([R3])c([R4])c1)C([R1])C2=O</smiles>

(+)-Catechin<smiles>[R10][R11]([H])([H])CO</smiles>

Baicalin<smiles>C1=Cc2cc3c4cc2[N+](=[N+]4CCO3)CCc2cc3c(cc21)OCO3</smiles>

Coptisine<smiles>COc1cc2c(cc1O)[C@H](c1ccc(O)c(O)c1)[C@H](CO)[C@H](CO)C2</smiles>

Isotaxiresinol<smiles>COc1ccc([C@@H]2CC(=O)c3c(O)cc(OC4O[C@@H](C(O)O)[C@@H](O)[C@H](O)[C@H]4O)cc3O2)cc1O</smiles>

Hesperidin<smiles>COc1ccc2ccc(=O)oc2c1CC=C(C)C</smiles><smiles>COC1CCc2c([nH]c3c2CCN=C3C)C1</smiles><smiles>COc1cc2c(cc1OC)-c1cc3ccc(OC)c(OC)c3c[n+]1CC2</smiles><smiles>COc1ccc2cc3[n+](cc2c1OC)CCc1cc2c(cc1-3)OCO2</smiles>

Osthole Harmine

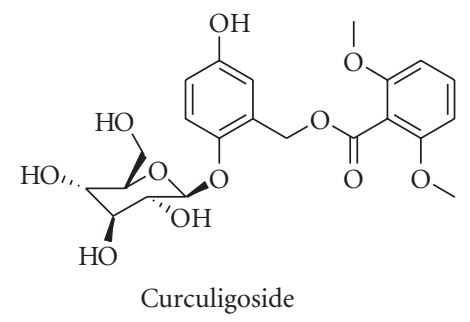

Curculigoside

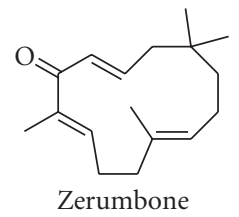

FIgURE 11: Continued. 

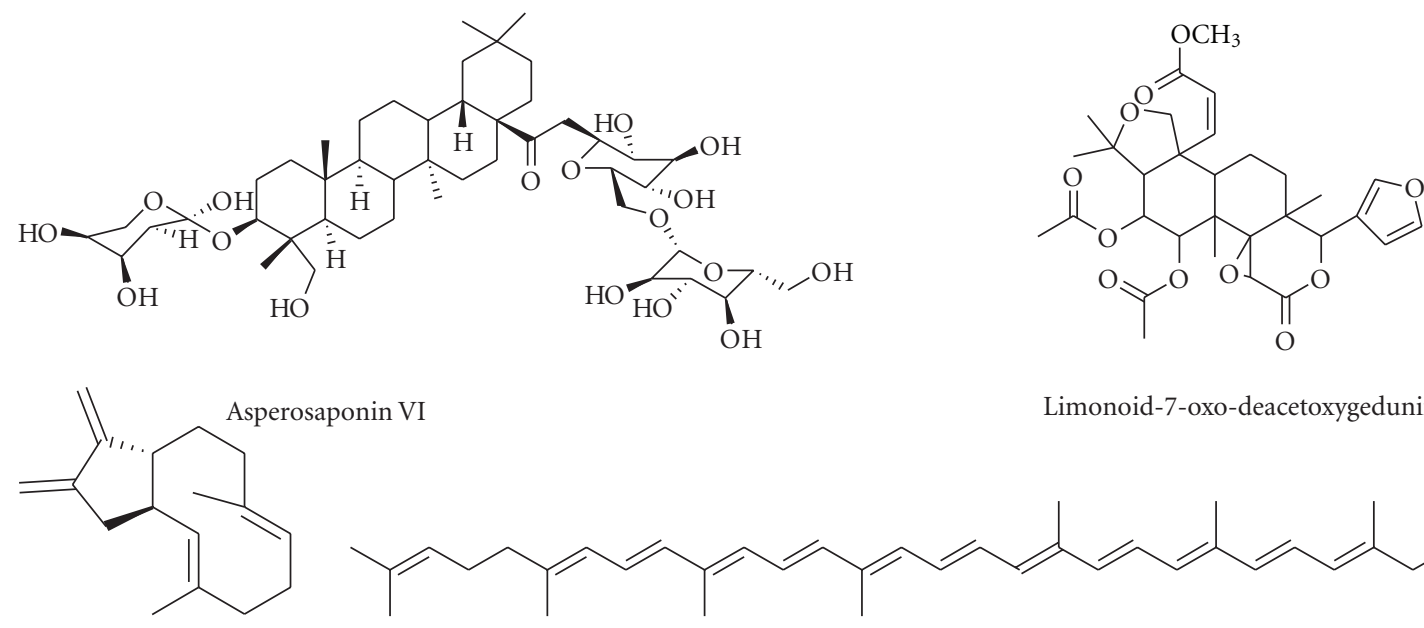

Limonoid-7-oxo-deacetoxygedunin<smiles>CC(C)=CCCC(C)=CC=CC(C)=CC=CC(C)=CC=CC(C)=CC=CC=C(C)C=CC=C(C)C=CC=C(C)CCCC(C)=CCCC(C)C</smiles>

Costunolide

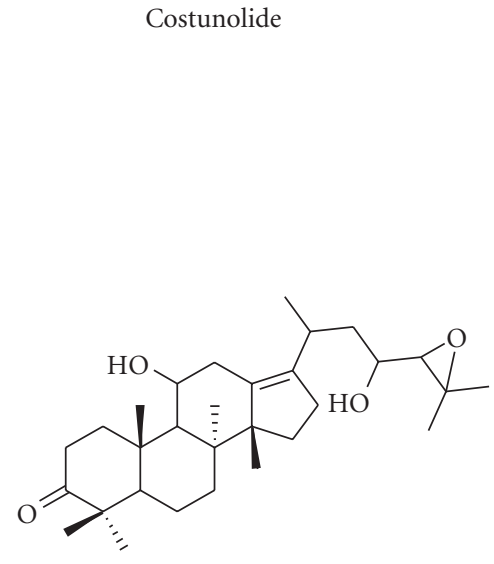

Alisol-B

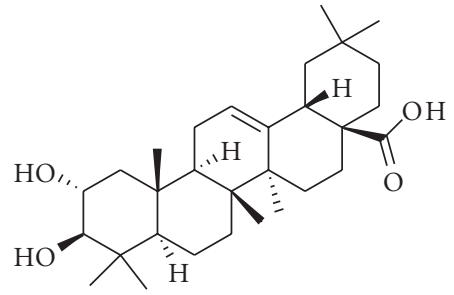

Maslinic acid

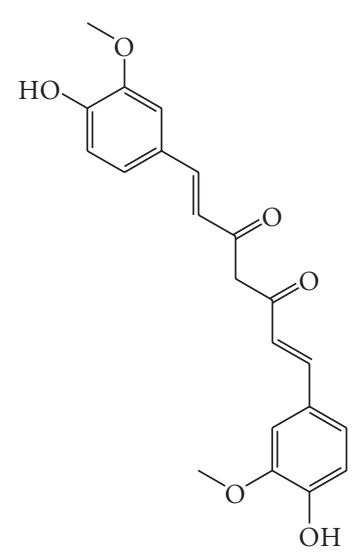

Curcumin

FIGURE 11: Chemical structure of compounds with antiosteoporotic activity.

3.2. Antiosteoporotic Compounds Isolated from Medicinal Plants. A wealth of information indicates numerous bioactive components isolated from plants with antiosteoporotic potential (Table 2, Figures 1-11). These compounds can be divided into 6 categories, including flavonoids: icariin (Figure 1) [23-26], genistein (Figure 2) [29], daidzein (Figure 2) [31, 32], kaempferol (Figure 11) [72], quercetin (Figure 11) [73, 74], naringin (Figure 8) [75-77], hesperidin (Figure 11) [78], linarin (Figure 11) [79], bavachalcone (Figure 3) [36], rutin (Figure 11) [80], (+)-catechin (Figure 11) [81], nobiletin (Figure 11) [82], luteolin (Figure 11) [83], baicalein (Figure 11) [84], baicalin (Figure 1) [85], xanthohumol (Figure 11) [86]; coumarins: psoralen (Figure 3) [35], osthole (Figure 11) [87]; lignans: honokiol (Figure 11) [88, 89], isotaxiresinol (Figure 11) [90], magnolol (Figure 11) [91]; polyphenol: resveratrol (Figure 11) [92-95], curcumin (Figure 11) [96-98], tea polyphenols (including epigallocatechin-3-gallate, epigallocatechin, epi-catechin, epicatechin-3-gallate, Figure 11) [99, 100]; anthraquinones: rubiadin (Figure 10), 2-hydroxy-1-methoxy-anthraquinone (Figure 10), 1,3,8trihydroxy-2-methoxy-anthraquinone (Figure 10) [71]; alkaloids: harmine (Figure 11) [101], coptisine (Figure 11) [102], palmatine (Figure 11) [103], berberine (Figure 11) $[104,105]$; and other compounds: curculigoside (Figure 11) [106, 107], asperosaponin VI (Figure 11) [108], limonoid 7-oxo-deacetoxygedunin (Figure 11) [109], zerumbone (Figure 11) [110], costunolide (Figure 11) [111], lycopene (Figure 11) [112, 113], tanshinone IIA (Figure 6) [49, 50], salvianolic acid A (Figure 6) [51], salvianolic acid B (Figure 6) [52], alisol-B (Figure 11) [114], and maslinic acid (Figure 11) [115].

Postmenopausal bone loss appears to be associated with the estrogen deficiency that leads to excessive osteoclastic and depressed osteoblastic activity [116], and possibly also impairs intestinal absorption of calcium [117]. In recent years, evidence has been provided linking bone loss to reactive oxygen species. Estrogen deficiency induces oxidative stress, impairs bone antioxidant system in adult rats, induces increase of lipid peroxidation and $\mathrm{H}_{2} \mathrm{O}_{2}$, and reduction of enzymatic antioxidants like SOD (super oxygen dehydrogenises) and GSH-Px (glutathione peroxidase) in rats [118]. Some phytochemicals, which have estrogen-like and/or antioxidative activity, produce bone protective effects, 
TABLE 2: Antiosteoporotic compounds isolated from medicinal plants.

\begin{tabular}{|c|c|c|}
\hline Compound & Pharmacological activity & reference \\
\hline \multicolumn{3}{|l|}{ Flavonoids } \\
\hline Icariin & See Section 3.1.1 & {$[23-26]$} \\
\hline Genistein & See Section 3.1 .2 & {$[29]$} \\
\hline Daidzein & $\begin{array}{l}\text { prevent bone loss in ovariectomized rats and } \\
\text { orchidectomized rats; } \\
\text { inhibit osteoclastic differentiation and bone resorption } \\
\text { by increasing the activity of mature osteoblasts via ER } \beta \text {, } \\
\text { regulating RUNX } 2 / C b f \alpha 1 \text { production, and stimulating } \\
\text { the secretion osteoprotegerin. }\end{array}$ & {$[31,32]$} \\
\hline Kaempferol & $\begin{array}{l}\text { increase ALP activity in cultured human MG-63 } \\
\text { osteoblasts through ERK and ER pathway; } \\
\text { prevent antimycin A-induced cell damage in } \\
\text { mitochondrial membrane potential dissipation, } \\
\text { complex IV inactivation, ROS production through } \\
\text { activation of PI3K (phosphoinositide 3-kinase), Akt } \\
\text { (protein kinase B), CREB (cAMP-response } \\
\text { element-binding protein) in MC3T3-E1. }\end{array}$ & {$[72]$} \\
\hline Quercetin & $\begin{array}{l}\text { reverse the decreased biomechanical quality and the } \\
\text { impaired microarchitecture of the femurs in diabetic } \\
\text { rats through improving antioxidant capacity; } \\
\text { inhibit osteoclastic differentiation and bone resorption } \\
\text { via inducing apoptosis and involving NF- } \kappa \text { B and AP- } 1 \text {. }\end{array}$ & {$[73,74]$} \\
\hline Naringin & $\begin{array}{l}\text { protect against retinoic acid-induced osteoporosis and } \\
\text { improve bone quality in rats; } \\
\text { perturb osteoclast formation and bone resorption by } \\
\text { inhibiting RANK-mediated NF- } \kappa \text { B and ERK signaling; } \\
\text { induce bone morphogenetic protein- } 2 \text { expression via } \\
\text { PI3K, Akt, c-Fos/c-Jun and AP-1 pathway in } \\
\text { osteoblasts; } \\
\text { prevent hydrogen peroxide-induced dysfunction in } \\
\text { osteoblastic MC3T3-E1 cells. }\end{array}$ & {$[75-77]$} \\
\hline Hesperidin & $\begin{array}{l}\text { protect bone loss in OVX rats, improve BMD and } \\
\text { femoral load in intact rats }\end{array}$ & {$[78]$} \\
\hline Linarin & $\begin{array}{l}\text { protect osteoblasts against hydrogen peroxide-induced } \\
\text { osteoblastic dysfunction, exert antiresorptive actions } \\
\text { via the reduction of RANKL and oxidative damage }\end{array}$ & {$[79]$} \\
\hline Bavachalcone & $\begin{array}{l}\text { inhibit osteoclastogenesis by interfering with the ERK } \\
\text { and Akt signaling pathways and the induction of c-Fos } \\
\text { and NFATc1. }\end{array}$ & {$[36]$} \\
\hline Rutin & $\begin{array}{l}\text { inhibit ovariectomy-induced trabecular bone loss in } \\
\text { rats by slowing down resorption and increasing } \\
\text { osteoblastic activity. }\end{array}$ & {$[80]$} \\
\hline$(+)$-Catechin & $\begin{array}{l}\text { enhance cell survival, alkaline phosphatase activity, } \\
\text { decrease bone-resorbing cytokines (TNF- } \alpha \text { and IL-6) } \\
\text { production and apoptosis in osteoblasts. }\end{array}$ & {$[81]$} \\
\hline Nobiletin & $\begin{array}{l}\text { prevent bone loss in ovariectomized rats; } \\
\text { suppress formation and bone resorption of osteoclast } \\
\text { induced by interleukin-1; } \\
\text { suppress the expression of cyclooxygenase- } 2 \text {, } \\
\text { NF- } \kappa \text { B-dependent transcription, and prostaglandin E } \\
\text { production in osteoblasts. }\end{array}$ & {$[82]$} \\
\hline Luteolin & $\begin{array}{l}\text { increase bone mineral density and bone mineral } \\
\text { content of trabecular and cortical bones in the femur of } \\
\text { OVX rats; } \\
\text { inhibit the differentiation of both bone marrow } \\
\text { mononuclear cells and RAW } 264.7 \text { cells into osteoclasts } \\
\text { and the bone resorptive activity of osteoclasts. }\end{array}$ & {$[83]$} \\
\hline
\end{tabular}


TABle 2: Continued.

\begin{tabular}{|c|c|c|}
\hline Compound & Pharmacological activity & reference \\
\hline Baicalein & $\begin{array}{l}\text { inhibit the differentiation and bone resorptive activity } \\
\text { of osteoclasts by inhibiting RANKL-induced activation } \\
\text { of signaling molecules (Akt, ERK/MAP kinase and } \\
\text { NF- } \kappa \text { B) and mRNA expression of osteoclast-associated } \\
\text { genes TRAP, matrix metalloproteinase } 9 \text { and c-Src, } \\
\text { c-Fos, Fra- } 2 \text { and NFATcl. }\end{array}$ & {$[84]$} \\
\hline Baicalin & $\begin{array}{l}\text { promote osteoblastic differentiation via } \mathrm{Wnt} / \beta \text {-catenin } \\
\text { signaling and enhance the mRNA expression of } \\
\text { osteoprotegerin }\end{array}$ & {$[85]$} \\
\hline Xanthohumol & $\begin{array}{l}\text { upregulate ALP activity and expression of osteogenic } \\
\text { marker genes by activation of RUNX } 2 \text { via mechanisms } \\
\text { related to the p38 MAPK and ERK signaling pathway }\end{array}$ & {$[86]$} \\
\hline \multicolumn{3}{|l|}{ Coumarins } \\
\hline Psoralen & $\begin{array}{l}\text { promote osteoblast differentiation by up-regulation of } \\
\text { expressions of osteoblast-specific marker through the } \\
\text { activation of BMP signaling }\end{array}$ & {$[35]$} \\
\hline Osthole & $\begin{array}{l}\text { prevent bone loss and improve bone microarchitecture, } \\
\text { histomorphometric parameters, and biomechanical } \\
\text { properties in OVX rats; } \\
\text { stimulate osteoblast proliferation and differentiation } \\
\text { through } \beta \text {-catenin/BMP signaling. }\end{array}$ & {$[87]$} \\
\hline \multicolumn{3}{|c|}{$\begin{array}{lllll} & \\
\end{array}$} \\
\hline Honokiol & $\begin{array}{l}\text { increase cell growth, alkaline phosphatase activity, } \\
\text { collagen synthesis, mineralization, glutathione content, } \\
\text { and osteoprotegerin release in the osteoblast; } \\
\text { decrease the production of TNF- } \alpha \text {, IL- } 6 \text {, and RANKL in } \\
\text { the presence of antimycin A; } \\
\text { stimulate osteoblastogenesis by suppressing NF- } \kappa \mathrm{B} \\
\text { activation. }\end{array}$ & {$[88,89]$} \\
\hline Isotaxiresinol & $\begin{array}{l}\text { improve bone mineral content, bone mineral density, } \\
\text { and bone strength indexes in OVX control rats; } \\
\text { slightly increase bone formation and significantly } \\
\text { inhibit bone resorption }\end{array}$ & {$[90]$} \\
\hline Magnolol & $\begin{array}{l}\text { cause a significant elevation of cell growth, alkaline } \\
\text { phosphatase activity, collagen synthesis, mineralization, } \\
\text { and glutathione content in osteoblast; } \\
\text { decrease the production of osteoclast differentiation } \\
\text { inducing factors such as RANKL, TNF- } \alpha \text {, and IL- } 6 \text { in } \\
\text { the presence of antimycin A }\end{array}$ & {$[91]$} \\
\hline \multicolumn{3}{|l|}{ Polyphenol } \\
\hline Resveratrol & $\begin{array}{l}\text { prevent osteoporosis induced by cyclosporin A; } \\
\text { inhibit the differentiation and bone resorbing activity } \\
\text { of osteoclasts through inhibition of ROS production; } \\
\text { promote the formation of osteoblasts by induction of } \\
\text { bone morphogenetic protein- } 2 \text { through Src } \\
\text { kinase-dependent estrogen receptor activation; } \\
\text { promote osteogenesis of human mesenchymal stem } \\
\text { cells by upregulating RUNX2 gene expression via the } \\
\text { SIRT1/FOXO3A axis. }\end{array}$ & [92-95] \\
\hline Curcumin & $\begin{array}{l}\text { improve bone microarchitecture and mineral density in } \\
\text { APP/PS1 transgenic mice; } \\
\text { improve bone strength and biochemical marker in } \\
\text { ovariectomized mature rat model; } \\
\text { inhibit OVX-induced bone loss by reducing } \\
\text { osteoclastogenesis through increasing antioxidant } \\
\text { activity and impairing RANKL signaling. }\end{array}$ & [96-98] \\
\hline
\end{tabular}


TABle 2: Continued.

Compound
Tea polyphenols (including
epigallocatechin-3-gallate,
epigallocatechin epi-catechin
epicatechin-3-gallate)
Anthraquinones
Rubiadin;
2-hydroxy-1-methoxy-
anthraquinone;
1,3,8-trihydroxy-2-methoxy-
anthraquinone

Alkaloids

Harmine

Coptisine

Palmatine

Berberine

Other compounds

Curculigoside

Asperosaponin VI

Limonoid

7-oxo-deacetoxygedunin

Zerumbone

Costunolide
Pharmacological activity

reference

attenuate trabecular and cortical bone loss through increasing bone formation while suppressing bone resorption due to its antioxidant capacity; inhibit the formation and differentiation of osteoclasts via inhibition of matrix metalloproteinases.

decrease bone resorption, the number of multinucleated osteoclasts, and the activity TRAP and cathepsin K of osteoclast;

induce the apoptosis of osteoclasts through improving the ratio of OPG and RANKL in osteoblasts, interfering with the JNK and NF- $\kappa \mathrm{B}$ signal pathway, and reducing the expression of calcitonin receptor and carbonic anhydrase/II in osteoclasts.

prevent bone loss in ovariectomized osteoporosis model mice;

inhibit osteoclast formation and bone resorption via

[101] downregulation of c-Fos and NFATc1 induced by RANKL.

inhibit RANKL-induced NF- $\kappa$ B phosphorylation in osteoclast precursors;

suppress the formation, differentiation and bone resorption of osteoclast through regulation of RANKL and OPG gene expression in osteoblastic cells

inhibit osteoclast formation and bone resorption in the co-culture system with mouse bone marrow cells (BMC) and osteoblasts; induce disruption of actin ring formation in mature osteoclasts with an impact on cell viability

prevent bone loss in SAMP6 senile osteoporosis model and ovariectomized rats;

inhibit formation and differentiation of osteoclast;

promote osteoblast differentiation through activation of Runx2 by p38 MAPK.

inhibit bone loss in ovariectomized mice; promote the proliferation and differentiation of osteoblast;

prevent hydrogen peroxide-induced dysfunction and

$[106,107]$ oxidative damage in calvarial osteoblasts; inhibit the formation, differentiation and bone resorption of osteoclast.

induce osteoblast maturation and differentiation, and bone formation via increasing BMP-2 synthesis and activating $\mathrm{p} 38$ and ERK1/2 pathway

inhibit RANKL-induced osteoclastogenesis by suppressing activation of the NF- $\kappa \mathrm{B}$ and MAPK pathways

abolish RANKL-induced NF- $\kappa$ B activation, inhibit osteoclastogenesis, and suppress human breast cancer-induced bone loss in athymic nude mice

stimulate the growth and differentiation of osteoblastic MC3T3-E1 cells, which may be associated with ER, PI3K, PKC, and MAPK signaling pathway 
TABle 2: Continued.

\begin{tabular}{|c|c|c|}
\hline Compound & Pharmacological activity & reference \\
\hline Lycopene & $\begin{array}{l}\text { reduce oxidative stress and the levels of bone turnover } \\
\text { markers in postmenopausal women; } \\
\text { stimulate proliferation and alkaline phosphatase } \\
\text { activity of osteoblasts; } \\
\text { inhibit osteoclasts formation and bone resorption } \\
\text { activity. }\end{array}$ & {$[112,113]$} \\
\hline Tanshinone IIA & $\begin{array}{l}\text { inhibit osteoclast differentiation and bone resorption } \\
\text { through disruption of the actin ring by inhibiting c-Fos } \\
\text { and NFATc1 expression. }\end{array}$ & {$[49,50]$} \\
\hline Salvianic acid $\mathrm{A}$ & $\begin{array}{l}\text { prevent bone loss from long-term administration of } \\
\text { prednisone in rats; } \\
\text { protect bone from glucocorticoid-induced bone } \\
\text { marrow impairment by stimulating osteogenesis and } \\
\text { depressing adipogenesis in bone marrow stromal cells. }\end{array}$ & {$[51]$} \\
\hline Salvianolic acid B & $\begin{array}{l}\text { prevent glucocorticoid-induced cancellous bone loss } \\
\text { and decrease adipogenesis; } \\
\text { stimulate bone marrow stromal cell differentiation to } \\
\text { osteoblast and increase osteoblast activities; } \\
\text { decrease glucocorticoid-induced associated } \\
\text { adipogenic differentiation through regulating the } \\
\text { mRNA expression of PPAR- } \gamma \text {, Runx2, Dickkopf-1 and } \\
\beta \text {-catenin in MSC }\end{array}$ & {$[52]$} \\
\hline Alisol-B & $\begin{array}{l}\text { prevent bone loss in mice; } \\
\text { inhibit osteoclastogenesis by inhibiting the } \\
\text { phosphorylation of JNK, and expression of NFATc1 } \\
\text { and c-Fos; } \\
\text { suppresses 2-methylene-19-nor- }(20 \mathrm{~S})-1 \alpha \text {, } \\
25(\mathrm{OH})_{2} \mathrm{D}_{3} \text {-induced hypercalcemia as resulting from } \\
\text { the inhibition of osteoclastogenesis }\end{array}$ & {$[114]$} \\
\hline Maslinic acid & $\begin{array}{l}\text { suppress osteoclastogenesis and prevent } \\
\text { ovariectomy-induced bone loss by regulating } \\
\text { RANKL-mediated NF- } \kappa \text { B and MAPK signaling pathway }\end{array}$ & {$[115]$} \\
\hline
\end{tabular}

via estrogen receptor and/or improving antioxidative capacity, and some may directly regulate the proliferation and activity of osteoblast and osteoclast [119].

Flavonoids, lignans, and coumarins, which are phytoestrogenic constituents, modulate the bone metabolism through estrogen receptor. Icariin, genistein, daidzein, kaempferol, and costunolide have been reported to decrease bone loss through increasing osteoblast proliferation and activity, via estrogen receptor. The phytochemicals with antioxidative capacity, such as kaempferol, quercetin, linarin, naringin, resveratrol, curcumin, tea polyphenols, curculigoside, and lycopene regulate bone metabolism through reducing the production of ROS and improving antioxidative capacity. Other compounds such as bavachalcone, (+)-catechin, nobiletin, luteolin, baicalein, baicalin, harmine, berberine, honokiol, osthole and tanshinone IIA, salvianolic acid B, alisol-B, and maslinic acid and so forth directly exert effects on osteoblst and osteoclast through modulating cytokines, and regulating pathway, such as MAPK, NF- $\kappa \mathrm{B}, \mathrm{Wnt} / \beta$ catenin, and RANKL/RANK/OPG pathway.

\section{Discussions and Conclusion}

Although chemical and biochemical agents such as bisphosphonates, estrogen, and calcitonin are the mainstay in the treatment of osteoporosis and controlling fracture, they have many side effects and fail to significantly alter the course of bone fracture complications. Plants are always an exemplary source of many currently available drugs. Clinical practice and folk experience have shown the possibility of obtaining natural products to recover osteoporosis and its complications. Chinese herbs, all of which come from natural products, are thought to treat osteoporosis mainly through, tonifying kidney and improving bone quality. Numerous medicinal plants can modulate bone metabolism to reduce bone loss [120]. Therefore, biological, chemical, and pharmacological methods should be applied to screen and obtain active lead compounds from natural medicinal plants for the treatment of osteoporosis and its complications.

There are two primary types of drugs used in the treatment of osteoporosis. One is antiresorptive agents which mainly inhibit bone resorption and the other is anabolic agents which mainly build bone. Most drugs act as agents against bone resorption, such as bisphosphonates, estrogen, selective estrogen receptor modulators (SERMs), and calcitonin which could reduce bone loss, stabilize the microarchitecture of the bone, and decrease bone turnover. However, the anabolic drugs increasing bone formation are relatively rare [5]. Teriparatide, a synthetic form of 
parathyroid hormone, is the only anabolic agent currently approved by the US Food and Drug Administration (FDA) for the treatment of osteoporosis. The anabolic therapy is now available for those individuals who continue to fracture or lose bone on an adequate program of general prevention and antiresorptive therapy [121]. Some medicinal plants not only inhibit bone resorption, but also increase new bone formation. So these plant medicines which can increase osteoblast proliferation activity and improve bone formation should be developed to satisfy patient needs. According to the clinical needs of the patients, doctors can select antiresorptive therapy or anabolic therapy or their combination.

There is good evidence that proper nutrition and lifestyle can promote bone health and pharmacotherapy can slow bone loss or even build new bone. However, there is still no "cure" for osteoporosis or for most other bone disorders. Those drugs that do exist, moreover, are still not ideal in terms of their expense, ease of administration, and/or side effects. When medicinal plants are being researched and developed for the treatment of osteoporosis, some questions should be considered. These questions include: (1) controllability: the effective chemical components of the drug should be clear and controllable. (2) Selectivity: the action of the drug should be specifically targeted to bone and to the molecule or rate-limiting process that is the cause of the disease. (3) Therapeutic index: the developed therapy should optimize the benefit-to-risk ratio of the drug. (4) Convenience: a more optimal drug should be the one that can be administered orally rather than parentally.

The safety of herbal remedies should also be considered. Although the popular view that herbals are natural and harmless, some herbal toxic effects have also be reported out of which, the hepatotoxicity is the most frequently reported toxic effect [122]. The investigation of compounds and composite formula regarding safety and toxicity is needed before definitive clinical guidelines can be made. On the other hand, the medicinal plants lack standardization; this makes it difficult to validate the plant use, and may discourage further studies. However, the chances of finding an active compound in a plant traced from ethnobotanical information are significantly higher than random chance in conventional techniques. Plants which are utilized often should be investigated for pharmacological and therapeutic effects in patients suffering from osteoporosis.

It is obvious that many plants have the potential to prevent and treat osteoporosis however, only a fraction of these plants have been thoroughly investigated so far. More efficient and reliable bioassays should be developed as a matter of urgency to systematically evaluate the antiosteoporotic efficacy of plant extracts, to identify the bioactive compounds responsible for the bone protective manifestation, and to elucidate antiosteoporotic mechanisms. In addition, as most antiosteoporotic agents from medicinal plants are prophylactic in nature rather than therapeutic and clinical trials have not yet been undertaken, the application of herbal agents are restricted. If such studies are encouraged and performed more herbal drugs for human use may soon be available.

\section{Author's Contribution}

M. Jia and Y. Nie contributed equally to this paper.

\section{Conflict of Interests}

The authors report no Conflict of interests.

\section{Acknowledgments}

The work was supported by National Natural Science Foundation of China $(81073115,81173191,81274152$, and 81202865) and Shanghai Committee of Science and Technology, China (12401900702).

\section{References}

[1] P. Sambrook and C. Cooper, “Osteoporosis," Lancet, vol. 367, no. 9527, pp. 2010-2018, 2006.

[2] T. D. Rachner, S. Khosla, and L. C. Hofbauer, "Osteoporosis: now and the future," The Lancet, vol. 377, no. 9773, pp. 12761287, 2011.

[3] P. J. Enriori and C. L. Enriori, "The pathogenesis of osteoporosis in older women and men: a review," Journal of Steroid Biochemistry and Molecular Biology, vol. 82, no. 1, pp. 1-6, 2002.

[4] F. Tremollieres and C. Ribot, "Bone mineral density and prediction of non-osteoporotic disease," Maturitas, vol. 65, no. 4 , pp. 348-351, 2010.

[5] J. C. Gallagher, "Advances in bone biology and new treatments for bone loss," Maturitas, vol. 60, no. 1, pp. 65-69, 2008.

[6] S. L. Teitelbaum, "Bone: the conundrum of glucocorticoidinduced of osteoporosis," Nature Reviews Endocrinology, vol. 8, no. 8, pp. 451-452, 2012.

[7] P. Moutsatsou, E. Kassi, and A. G. Papavassiliou, "Glucocorticoid receptor signaling in bone cells," Trends in Molecular Medicine, vol. 18, no. 6, pp. 348-359, 2012.

[8] D. Müller, J. Pulm, and A. Gandjour, "Cost-effectiveness of different strategies for selecting and treating individuals at increased risk of osteoporosis or osteopenia, a systematic review," Value in Health, vol. 15, no. 2, pp. 284-298, 2012.

[9] J. J. Body, P. Bergmann, S. Boonen et al., "Extraskeletal benefits and risks of calcium, Vitamin D and anti-osteoporosis medications," Osteoporosis International, vol. 23, supplement 1, pp. 1-23, 2012.

[10] D. A. Davey, "Update: estrogen and estrogen plus progestin therapy in the care of women at and after the menopause," Womens Health, vol. 8, no. 2, pp. 169-189, 2012.

[11] T. I. annitti, S. Rosini, D. Lodi, B. Frediani, V. Rottigni, and B. Palmieri, "Bisphosphonates: focus on inflammation and bone loss," American Journal of Therapeutics, vol. 19, no. 3, pp. 228-246, 2012.

[12] B. S. Komm and A. A. Chines, "An update on selective estrogen receptor modulators for the prevention and treatment of osteoporosis," Maturitas, vol. 71, no. 3, pp. 221-226, 2012.

[13] M. Saito and K. Marumo, "The effects of parathyroid hormone (teriparatide) on bone quality in osteoporosis," Clinical Calcium, vol. 22, no. 3, pp. 343-355, 2012.

[14] J. Y. Reginster and A. Neuprez, "Strontium ranelate: a look back at its use for osteoporosis," Expert Opinion on Pharmacotherapy, vol. 11, no. 17, pp. 2915-2927, 2010. 
[15] J. Compston, "The use of combination therapy in the treatment of postmenopausal osteoporosis," Endocrine, vol. 41, no. 1, pp. 11-18, 2012.

[16] G. Zhang, L. Qin, W. Y. Hung et al., "Flavonoids derived from herbal Epimedium brevicornum Maxim prevent OVXinduced osteoporosis in rats independent of its enhancement in intestinal calcium absorption," Bone, vol. 38, no. 6, pp. 818-825, 2006.

[17] D. W. Zhang, Y. Cheng, N. L. Wang, J. C. Zhang, M. S. Yang, and X. S. Yao, "Effects of total flavonoids and flavonol glycosides from Epimedium koreanum Nakai on the proliferation and differentiation of primary osteoblasts," Phytomedicine, vol. 15, no. 1-2, pp. 55-61, 2008.

[18] G. Qian, X. Zhang, L. Lu, X. Wu, S. Li, and J. Meng, "Regulation of Cbfa1 expression by total flavonoids of Herba Epimedii," Endocrine Journal, vol. 53, no. 1, pp. 87-94, 2006.

[19] P. Songlin, Z. Ge, H. Yixin et al., "Epimedium-derived flavonoids promote osteoblastogenesis and suppress adipogenesis in bone marrow stromal cells while exerting an anabolic effect on osteoporotic bone," Bone, vol. 45, no. 3, pp. 534-544, 2009.

[20] J. F. Zhang, G. Li, C. Y. Chan et al., "Flavonoids of Herba Epimedii regulate osteogenesis of human mesenchymal stem cells through BMP and Wnt/ $\beta$-catenin signaling pathway," Molecular and Cellular Endocrinology, vol. 314, no. 1, pp. 7074,2010

[21] H. Nian, M. H. Ma, S. S. Nian, and L. L. Xu, "Antiosteoporotic activity of icariin in ovariectomized rats," Phytomedicine, vol. 16, no. 4, pp. 320-326, 2009.

[22] T. P. Hsieh, S. Y. Sheu, J. S. Sun, and M. H. Chen, "Icariin inhibits osteoclast differentiation and bone resorption by suppression of MAPKs/NF- $\kappa$ B regulated HIF- $1 \alpha$ and PGE2 synthesis," Phytomedicine, vol. 18, no. 2-3, pp. 176-185, 2011.

[23] M. S. Wong, S. K. Mok, W. F. Chen et al., "Icariin protects against bone loss induced by oestrogen deficiency and activates oestrogen receptor-dependent osteoblastic functions in UMR 106 cells," British Journal of Pharmacology, vol. 159, no. 4, pp. 939-949, 2010.

[24] T. P. Hsieh, S. Y. Sheu, J. S. Sun, M. H. Chen, and M. H. Liu, "Icariin isolated from Epimedium pubescens regulates osteoblasts anabolism through BMP-2, SMAD4, and Cbfa1 expression," Phytomedicine, vol. 17, no. 6, pp. 414-423, 2010.

[25] H. J. Choi, J. S. Eun, Y. R. Park et al., "Ikarisoside A inhibits inducible nitric oxide synthase in lipopolysaccharidestimulated RAW 264.7 cells via p38 kinase and nuclear factorkappaB signaling pathways," European Journal of Pharmacology, vol. 601, no. 1-3, pp. 171-178, 2008.

[26] H. J. Choi, Y. R. Park, M. Nepal et al., "Inhibition of osteoclastogenic differentiation by Ikarisoside A in RAW 264.7 cells via JNK and NF-kappa B signaling pathways," European Journal of Pharmacology, vol. 636, no. 1-3, pp. 2835, 2010.

[27] S. M. Potter, J. A. Baum, H. Teng, R. J. Stillman, N. F. Shay, and J. W. Erdman, "Soy protein and isoflavones: their effects on blood lipids and bone density in postmenopausal women," American Journal of Clinical Nutrition, vol. 68, no. 6, pp. 1375S-1379S, 1998.

[28] K. Taku, M. K. Melby, N. Nishi, T. Omori, and M. S. Kurzer, "Soy isoflavones for osteoporosis: an evidence-based approach," Maturitas, vol. 70, no. 4, pp. 333-338, 2011.

[29] A. Bitto, F. Polito, B. Burnett et al., "Protective effect of genistein aglycone on the development of osteonecrosis of the femoral head and secondary osteoporosis induced by methylprednisolone in rats," Journal of Endocrinology, vol. 201, no. 3, pp. 321-328, 2009.

[30] A. Bitto, B. P. Burnett, F. Polito et al., "Genistein aglycone reverses glucocorticoid-induced osteoporosis and increases bone breaking strength in rats: a comparative study with alendronate," British Journal of Pharmacology, vol. 156, no. 8, pp. 1287-1295, 2009.

[31] M. Atteritano, S. Mazzaferro, A. Frisina et al., "Genistein effects on quantitative ultrasound parameters and bone mineral density in osteopenic postmenopausal women," Osteoporosis International, vol. 20, no. 11, pp. 1947-1954, 2009.

[32] B. Filipović, B. Šošić-Jurjević, V. Ajdžanović et al., "Daidzein administration positively affects thyroid $\mathrm{C}$ cells and bone structure in orchidectomized middle-aged rats," Osteoporosis International, vol. 21, no. 9, pp. 1609-1616, 2010.

[33] M. Komrakova, S. Sehmisch, M. Tezval et al., "Impact of 4-methylbenzylidene camphor, daidzein, and estrogen on intact and osteotomized bone in osteopenic rats," Journal of Endocrinology, vol. 211, no. 2, pp. 157-168, 2011.

[34] D. Wang, F. Li, and Z. Jiang, "Osteoblastic proliferation stimulating activity of Psoralea corylifolia extracts and two of its flavonoids," Planta Medica, vol. 67, no. 8, pp. 748-749, 2001.

[35] D. Xin, H. Wang, J. Yang et al., "Phytoestrogens from Psoralea corylifolia reveal estrogen receptor-subtype selectivity," Phytomedicine, vol. 17, no. 2, pp. 126-131, 2010.

[36] C. K. Park, Y. Lee, E. J. Chang et al., "Bavachalcone inhibits osteoclast differentiation through suppression of NFATc1 induction by RANKL," Biochemical Pharmacology, vol. 75, no. 11, pp. 2175-2182, 2008.

[37] D. Z. Tang, F. Yang, Z. Yang et al., "Psoralen stimulates osteoblast differentiation through activation of BMP signaling," Biochemical and Biophysical Research Communications, vol. 405, no. 2, pp. 256-261, 2011.

[38] X. Wang, J. Wu, H. Chiba, K. Yamada, and Y. Ishimi, "Puerariae radix prevents bone loss in castrated male mice," Metabolism, vol. 54, no. 11, pp. 1536-1541, 2005.

[39] X. Wang, J. Wu, H. Chiba, K. Umegaki, K. Yamada, and Y. Ishimi, "Puerariae radix prevents bone loss in ovariectomized mice," Journal of Bone and Mineral Metabolism, vol. 21, no. 5, pp. 268-275, 2003.

[40] J. Woo, E. Lau, S. C. Ho et al., "Comparison of Pueraria lobata with hormone replacement therapy in treating the adverse health consequences of menopause," Menopause, vol. 10, no. 4, pp. 352-361, 2003.

[41] Y. Zhang, X. Zeng, L. Zhang, and X. Zheng, "Stimulatory effect of puerarin on bone formation through activation of PI3K/Akt pathway in rat calvaria osteoblasts," Planta Medica, vol. 73, no. 4, pp. 341-347, 2007.

[42] N. Urasopon, Y. Hamada, K. Asaoka, W. Cherdshewasart, and S. Malaivijitnond, "Pueraria mirifica, a phytoestrogenrich herb, prevents bone loss in orchidectomized rats," Maturitas, vol. 56, no. 3, pp. 322-331, 2007.

[43] N. Urasopon, Y. Hamada, W. Cherdshewasart, and S. Malaivijitnond, "Preventive effects of Pueraria mirifica on bone loss in ovariectomized rats," Maturitas, vol. 59, no. 2, pp. 137-148, 2008.

[44] C. Circosta, R. De Pasquale, D. R. Palumbo, S. Samperi, and F. Occhiuto, "Effects of isoflavones from red clover (Trifolium pratense) on skin changes induced by ovariectomy in rats," Phytotherapy Research, vol. 20, no. 12, pp. 1096-1099, 2006.

[45] V. Beck, U. Rohr, and A. Jungbauer, "Phytoestrogens derived from red clover: an alternative to estrogen replacement 
therapy?" Journal of Steroid Biochemistry and Molecular Biology, vol. 94, no. 5, pp. 499-518, 2005.

[46] S. Geller and L. Studee, "Soy and red clover for mid-life and aging," Climacteric, vol. 9, no. 4, pp. 245-263, 2006.

[47] S. Kawakita, F. Marotta, Y. Naito et al., "Effect of an isoflavones-containing red clover preparation and alkaline supplementation on bone metabolism in ovariectomized rats," Clinical Interventions in Aging, vol. 4, no. 1, pp. 91-100, 2009.

[48] H. K. Kim, E. R. Woo, H. W. Lee et al., "The correlation of Salvia miltiorrhiza extract-induced regulation of osteoclastogenesis with the amount of components tanshinone I, tanshinone IIA, cryptotanshinone, and dihydrotanshinone," Immunopharmacology and Immunotoxicology, vol. 30, no. 2, pp. 347-364, 2008.

[49] H. J. Chae, S. W. Chae, D. H. Yun, K. S. Keum, S. K. Yoo, and H. R. Kim, "Prevention of bone loss in ovariectomized rats: the effect of Salvia miltiorrhiza extracts," Immunopharmacology and Immunotoxicology, vol. 26, no. 1, pp. 135-144, 2004.

[50] B. K. Han, D. Yang, H. Ha et al., "Tanshinone IIA inhibits osteoclast differentiation through down-regulation of c-Fos and NFATc1," Experimental and Molecular Medicine, vol. 38, no. 3, pp. 256-264, 2006.

[51] L. Cui, Y. Y. Liu, T. Wu, C. M. Ai, and H. Q. Chen, "Osteogenic effects of $\mathrm{D}(+) \beta$-3, 4-dihydroxyphenyl lactic acid (salvianic acid A, SAA) on osteoblasts and bone marrow stromal cells of intact and prednisone-treated rats," Acta Pharmacologica Sinica, vol. 30, no. 3, pp. 321-332, 2009.

[52] L. Cui, T. Li, Y. Liu et al., "Salvianolic acid B prevents bone loss in prednisone-treated rats through stimulation osteogenensis and bone marrow angiogenesis," PLoS One, vol. 7, no. 4, Article ID e34647, 2012.

[53] S. M. Sacco, J. M. Y. Jiang, S. Reza-López, D. W. L. Ma, L. U. Thompson, and W. E. Ward, "Flaxseed combined with low-dose estrogen therapy preserves bone tissue in ovariectomized rats," Menopause, vol. 16, no. 3, pp. 545-554, 2009.

[54] S. Boulbaroud, A. Mesfioui, A. Arfaoui, A. Ouichou, and A. El Hessni, "Preventive effects of flaxseed and sesame oil on bone loss in ovariectomized rats," Pakistan Journal of Biological Sciences, vol. 11, no. 13, pp. 1696-1701, 2008.

[55] D. B. Kettler, "Can manipulation of the ratios of essential fatty acids slow the rapid rate of postmenopausal bone loss?" Alternative Medicine Review, vol. 6, no. 1, pp. 61-77, 2001.

[56] B. H. Arjmandi, "The role of phytoestrogens in the prevention and treatment of osteoporosis in ovarian hormone deficiency," Journal of the American College of Nutrition, vol. 20, no. 5, supplement, pp. 398S-402S, 2001.

[57] J. C. Jeong, J. W. Lee, C. H. Yoon, H. M. Kim, and C. H. Kim, "Drynariae Rhizoma promotes osteoblast differentiation and mineralization in MC3T3-E1 cells through regulation of bone morphogenetic protein-2, alkaline phosphatase, type I collagen and collagenase-1," Toxicology in vitro, vol. 18, no. 6, pp. 829-834, 2004.

[58] X. L. Wang, N. L. Wang, Y. Zhang et al., "Effects of eleven flavonoids from the osteoprotective fraction of Drynaria fortunei (Kunze) J. Sm. on osteoblastic proliferation using an osteoblast-like cell line," Chemical and Pharmaceutical Bulletin, vol. 56, no. 1, pp. 46-51, 2008.

[59] X. Wang, L. Zhen, G. Zhang, M. S. Wong, L. Qin, and X. Yao, "Osteogenic effects of flavonoid aglycones from an osteoprotective fraction of Drynaria fortunei-an in vitro efficacy study," Phytomedicine, vol. 18, no. 10, pp. 868-872, 2011.
[60] J. C. Eun, J. L. Won, H. C. Sung, and W. C. Sang, "Proliferative effects of flavan-3-ols and propelargonidins from rhizomes of Drynaria fortunei on MCF-7 and osteoblastic cells," Archives of Pharmacal Research, vol. 26, no. 8, pp. 620630, 2003.

[61] D. Guo, J. Wang, X. Wang et al., "Double directional adjusting estrogenic effect of naringin from Rhizoma drynariae (Gusuibu)," Journal of Ethnopharmacology, vol. 138, pp. 451457, 2011.

[62] D. Seidlová-Wuttke, H. Jarry, T. Becker, V. Christoffel, and W. Wuttke, "Pharmacology of Cimicifuga racemosa extract BNO 1055 in rats: bone, fat and uterus," Maturitas, vol. 44, supplement, pp. S39-S50, 2003.

[63] W. Wuttke, D. Seidlová-Wuttke, and C. Gorkow, "The Cimicifuga preparation BNO 1055 versus conjugated estrogens in a double-blind placebo-controlled study: effects on menopause symptoms and bone markers," Maturitas, vol. 44, supplement, pp. S67-S77, 2003.

[64] E. M. Choi, "Deoxyactein stimulates osteoblast function and inhibits bone-resorbing mediators in MC3T3-E1 cells," Journal of Applied Toxicology. In press.

[65] V. Viereck, C. Gründker, S. C. Friess et al., "Isopropanolic extract of black cohosh stimulates osteoprotegerin production by human osteoblasts," Journal of Bone and Mineral Research, vol. 20, no. 11, pp. 2036-2043, 2005.

[66] L. Kolios, J. Schumann, S. Sehmisch et al., "Effects of black cohosh (Cimicifuga racemosa) and estrogen on metaphyseal fracture healing in the early stage of osteoporosis in ovariectomized rats," Planta Medica, vol. 76, no. 9, pp. 850-857, 2010.

[67] B. I. Seo, S. K. Ku, E. M. Cha et al., "Effect of Mornidae radix extracts on experimental osteoporosis in sciatic neurectomized mice," Phytotherapy Research, vol. 19, no. 3, pp. 231238, 2005.

[68] N. Li, L. P. Qin, T. Han, Y. B. Wu, Q. Y. Zhang, and H. Zhang, "Inhibitory effects of Morinda officinalis extract on bone loss in ovariectomized rats," Molecules, vol. 14, no. 6, pp. 20492061, 2009.

[69] Z. MengYong, W. Caijiao, Z. HuSheng, P. XianWu, and F. JianMin, "Protective effect of polysaccharides from Morinda officinalis on bone loss in ovariectomized rats," International Journal of Biological Macromolecules, vol. 43, no. 3, pp. 276278, 2008.

[70] Y. B. Wu, C. J. Zheng, L. P. Qin et al., "Antiosteoporotic activity of anthraquinones from Morinda officinalis on osteoblasts and osteoclasts," Molecules, vol. 14, no. 1, pp. 573583, 2009.

[71] L. Bao, L. Qin, L. Liu et al., "Anthraquinone compounds from Morinda officinalis inhibit osteoclastic bone resorption in vitro," Chemico-Biological Interactions, vol. 194, no. 2-3, pp. 97-105, 2011.

[72] E. M. Choi, "Kaempferol protects MC3T3-E1 cells through antioxidant effect and regulation of mitochondrial function," Food and Chemical Toxicology, vol. 49, no. 8, pp. 1800-1805, 2011.

[73] W. Liang, Z. Luo, S. Ge et al., "Oral administration of quercetin inhibits bone loss in rat model of diabetic osteopenia," European Journal of Pharmacology, vol. 670, no. 1, pp. 317-324, 2011.

[74] J. Inoue, J. M. Choi, T. Yoshidomi, T. Yashiro, and R. Sato, "Quercetin enhances VDR activity, leading to stimulation of its target gene expression in Caco-2 Cells," Journal of Nutritional Science and Vitaminology, vol. 56, no. 5, pp. 326330, 2010. 
[75] P. Zhang, K. R. Dai, S. G. Yan et al., "Effects of naringin on the proliferation and osteogenic differentiation of human bone mesenchymal stem cell," European Journal of Pharmacology, vol. 607, no. 1-3, pp. 11-15, 2009.

[76] J. B. Wu, Y. C. Fong, H. Y. Tsai, Y. F. Chen, M. Tsuzuki, and C. H. Tang, "Naringin-induced bone morphogenetic protein-2 expression via PI3K, Akt, c-Fos/c-Jun and AP-1 pathway in osteoblasts," European Journal of Pharmacology, vol. 588, no. 2-3, pp. 333-341, 2008.

[77] E. S. Ang, X. Yang, H. Chen, Q. Liu, M. H. Zheng, and J. Xu, "Naringin abrogates osteoclastogenesis and bone resorption via the inhibition of RANKL-induced NF-kappaB and ERK activation," FEBS Letters, vol. 585, no. 17, pp. 2755-2762, 2011.

[78] M. N. Horcajada, V. Habauzit, A. Trzeciakiewicz et al., "Hesperidin inhibits ovariectomized-induced osteopenia and shows differential effects on bone mass and strength in young and adult intact rats," Journal of Applied Physiology, vol. 104, no. 3, pp. 648-654, 2008.

[79] Y. H. Kim, Y. S. Lee, and E. M. Choi, "Linarin isolated from Buddleja officinalis prevents hydrogen peroxideinduced dysfunction in osteoblastic MC3T3-E1 cells," Cellular Immunology, vol. 268, no. 2, pp. 112-116, 2011.

[80] M. N. Horcajada-Molteni, V. Crespy, V. Coxam, M. J. Davicco, C. Remesy, and J. P. Barlet, "Rutin inhibits ovariectomy-induced osteopenia in rats," Journal of Bone and Mineral Research, vol. 15, no. 11, pp. 2251-2258, 2000.

[81] E. M. Choi and J. K. Hwang, "Effects of (+)-catechin on the function of osteoblastic cells," Biological and Pharmaceutical Bulletin, vol. 26, no. 4, pp. 523-526, 2003.

[82] S. Harada, T. Tominari, C. Matsumoto et al., "Nobiletin, a polymethoxy flavonoid, suppresses bone resorption by inhibiting NF $\kappa \mathrm{B}$-dependent prostaglandin $\mathrm{E}$ synthesis in osteoblasts and prevents bone loss due to estrogen deficiency," Journal of Pharmacological Sciences, vol. 115, no. 1, pp. 89-93, 2011.

[83] T. H. Kim, J. W. Jung, B. G. Ha et al., "The effects of luteolin on osteoclast differentiation, function in vitro and ovariectomy-induced bone loss," Journal of Nutritional Biochemistry, vol. 22, no. 1, pp. 8-15, 2011.

[84] M. H. Kim, S. Y. Ryu, M. A. Bae, J. S. Choi, Y. K. Min, and S. H. Kim, "Baicalein inhibits osteoclast differentiation and induces mature osteoclast apoptosis," Food and Chemical Toxicology, vol. 46, no. 11, pp. 3375-3382, 2008.

[85] A. J. Guo, R. C. Choi, A. W. Cheung et al., "Baicalin, a flavone, induces the differentiation of cultured osteoblasts: an action via the Wnt/beta-catenin signaling pathway," Journal of Biological Chemistry, vol. 286, no. 32, pp. 27882-27893, 2011.

[86] H. M. Jeong, E. H. Han, Y. H. Jin, Y. H. Choi, K. Y. Lee, and H. G. Jeong, "Xanthohumol from the hop plant stimulates osteoblast differentiation by RUNX2 activation," Biochemical and Biophysical Research Communications, vol. 409, no. 1, pp. 82-89, 2011.

[87] Q. Zhang, L. Qin, W. He et al., "Coumarins from Cnidium monnieri and their antiosteoporotic activity," Planta Medica, vol. 73, no. 1, pp. 13-19, 2007.

[88] E. M. Choi, "Honokiol isolated from Magnolia officinalis stimulates osteoblast function and inhibits the release of bone-resorbing mediators," International Immunopharmacology, vol. 11, no. 10, pp. 1541-1545, 2011.

[89] E. M. Choi, "Honokiol protects osteoblastic MC3T3-E1 cells against antimycin A-induced cytotoxicity," Inflammation Research, vol. 60, no. 11, pp. 1005-1012, 2011.
[90] J. Yin, Y. Tezuka, Subehan et al., "In vivo anti-osteoporotic activity of isotaxiresinol, a lignan from wood of Taxus yunnanensis," Phytomedicine, vol. 13, no. 1-2, pp. 37-42, 2006.

[91] E. M. Choi, "Magnolol protects osteoblastic MC3T3-E1 cells against antimycin A-induced cytotoxicity through activation of mitochondrial function," Inflammation, vol. 35, no. 3, pp. 1204-1212, 2012.

[92] L. H. Song, W. Pan, Y. H. Yu, L. D. Quarles, H. H. Zhou, and Z. S. Xiao, "Resveratrol prevents CsA inhibition of proliferation and osteoblastic differentiation of mouse bone marrow-derived mesenchymal stem cells through an ER/NO/cGMP pathway," Toxicology in Vitro, vol. 20, no. 6, pp. 915-922, 2006.

[93] X. He, G. Andersson, U. Lindgren, and Y. Li, "Resveratrol prevents RANKL-induced osteoclast differentiation of murine osteoclast progenitor RAW 264.7 cells through inhibition of ROS production," Biochemical and Biophysical Research Communications, vol. 401, no. 3, pp. 356-362, 2010.

[94] M. Shakibaei, C. Buhrmann, and A. Mobasheri, "Resveratrolmediated SIRT-1 interactions with p300 modulate receptor activator of NF- $\kappa \mathrm{B}$ ligand (RANKL) activation of NF- $\kappa \mathrm{B}$ Signaling and inhibit osteoclastogenesis in bone-derived cells," Journal of Biological Chemistry, vol. 286, no. 13, pp. 11492-11505, 2011.

[95] P. C. Tseng, S. M. Hou, R. J. Chen et al., "Resveratrol promotes osteogenesis of human mesenchymal stem cells by upregulating RUNX2 gene expression via the SIRT1/FOXO3A axis," Journal of Bone and Mineral Research, vol. 26, no. 10, pp. 2552-2563, 2011.

[96] M. W. Yang, T. H. Wang, P. P. Yan et al., "Curcumin improves bone microarchitecture and enhances mineral density in APP/PS1 transgenic mice," Phytomedicine, vol. 18, no. 2-3, pp. 205-213, 2011.

[97] D. L. French, J. M. Muir, and C. E. Webber, "The ovariectomized, mature rat model of postmenopausal osteoporosis: an assessment of the bone sparing effects of curcumin," Phytomedicine, vol. 15, no. 12, pp. 1069-1078, 2008.

[98] W. K. Kim, K. Ke, O. J. Sul et al., "Curcumin protects against ovariectomy-induced bone loss and decreases osteoclastogenesis," Journal of Cellular Biochemistry, vol. 112, no. 11, pp. 3159-3166, 2011.

[99] M. Kamon, R. Zhao, and K. Sakamoto, "Green tea polyphenol (-)-epigallocatechin gallate suppressed the differentiation of murine osteoblastic MC3T3-E1 cells," Cell Biology International, vol. 34, no. 1, pp. 109-116, 2010.

[100] C. L. Shen, P. Wang, J. Guerrieri, J. K. Yeh, and J. S. Wang, "Protective effect of green tea polyphenols on bone loss in middle-aged female rats," Osteoporosis International, vol. 19, no. 7, pp. 979-990, 2008.

[101] T. Yonezawa, S. I. Hasegawa, M. Asai et al., "Harmine, a $\beta$-carboline alkaloid, inhibits osteoclast differentiation and bone resorption in vitro and in vivo," European Journal of Pharmacology, vol. 650, no. 2-3, pp. 511-518, 2011.

[102] J. W. Lee, A. Iwahashi, S. I. Hasegawa et al., "Coptisine inhibits RANKL-induced NF- $\kappa$ B phosphorylation in osteoclast precursors and suppresses function through the regulation of RANKL and OPG gene expression in osteoblastic cells," Journal of Natural Medicines, vol. 66, no. 1, pp. 8-16, 2011.

[103] J. W. Lee, N. Mase, T. Yonezawa et al., "Palmatine attenuates osteoclast differentiation and function through inhibition of receptor activator of nuclear factor- $\kappa \mathrm{B}$ ligand expression in 
osteoblast cells," Biological and Pharmaceutical Bulletin, vol. 33, no. 10, pp. 1733-1739, 2010.

[104] H. Li, T. Miyahara, Y. Tezuka, Q. Le Tran, H. Seto, and S. Kadota, "Effect of berberine on bone mineral density in SAMP6 as a senile osteoporosis model," Biological and Pharmaceutical Bulletin, vol. 26, no. 1, pp. 110-111, 2003.

[105] W. L. Hyun, H. S. Jung, H. N. Kim et al., "Berberine promotes osteoblast differentiation by Runx2 activation with p38 MAPK," Journal of Bone and Mineral Research, vol. 23, no. 8, pp. 1227-1237, 2008.

[106] L. Jiao, D. P. Cao, L. P. Qin et al., "Antiosteoporotic activity of phenolic compounds from Curculigo orchioides," Phytomedicine, vol. 16, no. 9, pp. 874-881, 2009.

[107] Y. Wang, L. Zhao, Y. Wang et al., "Curculigoside isolated from Curculigo orchioides prevents hydrogen peroxide-induced dysfunction and oxidative damage in calvarial osteoblasts," Acta Biochimica et Biophysica Sinica, vol. 44, no. 5, pp. 431441, 2012.

[108] Y. Niu, Y. Li, H. Huang et al., "Asperosaponin VI, a saponin component from Dipsacus asper wall, induces osteoblast differentiation through bone morphogenetic protein-2/p38 and extracellular signal-regulated kinase 1/2 pathway," Phytotherapy Research, vol. 25, no. 11, pp. 1700-1706, 2011.

[109] C. Wisutsitthiwong, C. Buranaruk, K. Pudhom, and T. Palaga, "The plant limonoid 7-oxo-deacetoxygedunin inhibits RANKL-induced osteoclastogenesis by suppressing activation of the NF-kappaB and MAPK pathways," Biochemical and Biophysical Research Communications, vol. 415, no. 2, pp. 361-366, 2011.

[110] B. Sung, A. Murakami, B. O. Oyajobi, and B. B. Aggarwal, "Zerumbone abolishes RaNKL-induced NF- $\kappa$ B activation, inhibits osteoclastogenesis, and suppresses human breast cancer-induced bone loss in athymic nude mice," Cancer Research, vol. 69, no. 4, pp. 1477-1484, 2009.

[111] Y. S. Lee and E. M. Choi, "Costunolide stimulates the function of osteoblastic MC3T3-E1 cells," International Immunopharmacology, vol. 11, no. 6, pp. 712-718, 2011.

[112] S. Sahni, M. T. Hannan, J. Blumberg, L. A. Cupples, D. P. Kiel, and K. L. Tucker, "Protective effect of total carotenoid and lycopene intake on the risk of hip fracture: a 17-year follow-up from the Framingham osteoporosis atudy," Journal of Bone and Mineral Research, vol. 24, no. 6, pp. 1086-1094, 2009.

[113] E. S. MacKinnon, A. V. Rao, R. G. Josse, and L. G. Rao, "Supplementation with the antioxidant lycopene significantly decreases oxidative stress parameters and the bone resorption marker N-telopeptide of type i collagen in postmenopausal women," Osteoporosis International, vol. 22, no. 4, pp. 10911101, 2011.

[114] J. W. Lee, Y. Kobayashi, Y. Nakamichi et al., "Alisol-B, a novel phyto-steroid, suppresses the RANKL-induced osteoclast formation and prevents bone loss in mice," Biochemical Pharmacology, vol. 80, no. 3, pp. 352-361, 2010.

[115] C. Li, Z. Yang, Z. Li et al., "Maslinic acid suppresses osteoclastogenesis and prevents ovariectomy-induced bone loss by regulating RANKL-mediated NF- $\kappa$ B and MAPK signaling pathways," Journal of Bone and Mineral Research, vol. 26, no. 3, pp. 644-656, 2011.

[116] L. G. Raisz, “The osteoporosis revolution," Annals of Internal Medicine, vol. 126, no. 6, pp. 458-462, 1997.

[117] P. D. O'Loughlin and H. A. Morris, "Oestrogen deficiency impairs intestinal calcium absorption in the rat," Journal of Physiology, vol. 511, no. 1, pp. 313-322, 1998.
[118] J. M. Lean, J. T. Davies, K. Fuller et al., "A crucial role for thiol antioxidants in estrogen-deficiency bone loss," Journal of Clinical Investigation, vol. 112, no. 6, pp. 915-923, 2003.

[119] C. Puel, A. Quintin, A. Agalias et al., "Olive oil and its main phenolic micronutrient (oleuropein) prevent inflammationinduced bone loss in the ovariectomised rat," British Journal of Nutrition, vol. 92, no. 1, pp. 119-127, 2004.

[120] M. Xu, C. Qi, B. Deng, P. X. Deng, and C. W. Mo, "Phytotherapy versus hormonal therapy for postmenopausal bone loss: a meta-analysis," Osteoporosis International, vol. 20, no. 4, pp. 519-526, 2009.

[121] G. Resmini and G. Iolascon, "New insights into the teriparatide," Aging Clinical and Experimental Research, vol. 23, no. 2, supplement, pp. 30-32, 2011.

[122] S. C. Man, K. W. Chan, J. H. Lu et al., "Systematic review on the efficacy and safety of herbal medicines for vascular dementia," Evidence-Based Complementary and Alternative Medicine, vol. 2012, Article ID 426215, 22 pages, 2012.

[123] C. C. He, R. R. Hui, Y. Tezuka, S. Kadota, and J. X. Li, “Osteoprotective effect of extract from Achyranthes bidentata in ovariectomized rats," Journal of Ethnopharmacology, vol. 127, no. 2, pp. 229-234, 2010.

[124] R. Zhang, S. J. Hu, C. Li, F. Zhang, H. Q. Gan, and Q. B. Mei, "Achyranthes bidentata root extract prevent OVX-induced osteoporosis in rats," Journal of Ethnopharmacology, vol. 139, no. 1, pp. 12-18, 2010.

[125] D. P. Cao, Y. N. Zheng, L. P. Qin et al., "Curculigo orchioides, a traditional Chinese medicinal plant, prevents bone loss in ovariectomized rats," Maturitas, vol. 59, no. 4, pp. 373-380, 2008.

[126] J. M. Liao, Q. A. Zhu, H. J. Lu, Q. N. Li, T. Wu, and L. F. Huang, "Effects of total coumarins of Cnidium monnieri on bone density and biomechanics of glucocorticoids-induced osteoporosis in rats," Acta Pharmacologica Sinica, vol. 18, no. 6, pp. 519-521, 1997.

[127] C. Y. Li, T. Wu, Q. N. Li et al., "Effects of fructus Cnidii coumarins compared with nilestriol on osteoporosis in ovariectomized rats," Zhongguo Yao Li Xue Bao, vol. 18, no. 3, pp. 286-288, 1997.

[128] S. S. Shirke, S. R. Jadhav, and A. G. Jagtap, "Methanolic extract of cuminum cyminum inhibits ovariectomy-induced bone loss in rats," Experimental Biology and Medicine, vol. 233, no. 11, pp. 1403-1410, 2008.

[129] M. Ferretti, L. Bertoni, F. Cavani et al., "Influence of ferutinin on bone metabolism in ovariectomized rats. II: role in recovering osteoporosis," Journal of Anatomy, vol. 217, no. 1, pp. 48-56, 2010.

[130] Q. Yang, S. M. Populo, J. Zhang, G. Yang, and H. Kodama, "Effect of Angelica sinensis on the proliferation of human bone cells," Clinica Chimica Acta, vol. 324, no. 1-2, pp. 8997, 2002.

[131] Y. Shen, Y. Q. Li, S. P. Li, L. Ma, L. J. Ding, and H. Ji, "Alleviation of ovariectomy-induced osteoporosis in rats by Panax notoginseng saponins," Journal of Natural Medicines, vol. 64, no. 3, pp. 336-345, 2010.

[132] X. D. Li, J. S. Wang, B. Chang et al., "Panax notoginseng saponins promotes proliferation and osteogenic differentiation of rat bone marrow stromal cells," Journal of Ethnopharmacology, vol. 134, no. 2, pp. 268-274, 2011.

[133] Y. C. Hwang, I. K. Jeong, K. J. Ahn, and H. Y. Chung, "The effects of Acanthopanax senticosus extract on bone turnover and bone mineral density in Korean postmenopausal women," Journal of Bone and Mineral Metabolism, vol. 27, no. 5, pp. 584-590, 2009. 
[134] H. S. Yogesh, V. M. Chandrashekhar, H. R. Katti et al., "Antiosteoporotic activity of aqueous-methanol extract of Berberis aristata in ovariectomized rats," Journal of Ethnopharmacology, vol. 134, no. 2, pp. 334-338, 2011.

[135] V. M. Pattell, Berberis Aristata Plants Extracts for Treating Osteoporosis and the Extraction Process Thereof, Avestha Gengraine Technologies PVT, 2008, http://patentscope.wipo .int/search/en/WO2008007215.

[136] Y. Zhang, L. Yu, M. Ao, and W. Jin, "Effect of ethanol extract of Lepidium meyenii Walp. on osteoporosis in ovariectomized rat," Journal of Ethnopharmacology, vol. 105, no. 1-2, pp. 274 279, 2006.

[137] G. F. Gonzales, "Ethnobiology and ethnopharmacology of Lepidium meyenii (Maca), a plant from the Peruvian Highlands," Evidence-Based Complementary and Alternative Medicine, vol. 2012, Article ID 193496, 10 pages, 2012.

[138] H. M. Jeong, E. H. Han, Y. H. Jin et al., "Saponins from the roots of Platycodon grandiflorum stimulate osteoblast differentiation via p38 MAPK- and ERK-dependent RUNX2 activation," Food and Chemical Toxicology, vol. 48, no. 12, pp. 3362-3368, 2010.

[139] Y. Zhang, Q. Li, H. Y. Wan et al., "Study of the mechanisms by which Sambucus williamsii HANCE extract exert protective effects against ovariectomy-induced osteoporosis in vivo," Osteoporosis International, vol. 22, no. 2, pp. 703-709, 2011.

[140] H. J. Kim, Y. C. Bae, R. W. Park et al., "Bone-protecting effect of safflower seeds in ovariectomized rats," Calcified Tissue International, vol. 71, no. 1, pp. 88-94, 2002.

[141] Y. S. Lee, C. W. Choi, J. J. Kim, A. Ganapathi, R. Udayakumar, and S. C. Kim, "Determination of mineral content in methanolic safflower (Carthamus tinctorius L.) seed extract and its effect on osteoblast markers," International Journal of Molecular Sciences, vol. 10, no. 1, pp. 292-305, 2009.

[142] J. L. Kim, S. W. Kang, M. K. Kang et al., "Osteoblastogenesis and osteoprotection enhanced by flavonolignan silibinin in osteoblasts and osteoclasts," Journal of Cellular Biochemistry, vol. 113, no. 1, pp. 247-259, 2012.

[143] N. A. El-Shitany, S. Hegazy, and K. El-desoky, "Evidences for antiosteoporotic and selective estrogen receptor modulator activity of silymarin compared with ethinylestradiol in ovariectomized rats," Phytomedicine, vol. 17, no. 2, pp. 116$125,2010$.

[144] S. Annie, R. G. Prabhu, and S. Malini, "Activity of Wedelia calendulacea Less. in post-menopausal osteoporosis," Phytomedicine, vol. 13, no. 1-2, pp. 43-48, 2006.

[145] Y. Ding, C. Liang, S. Y. Yang et al., "Phenolic compounds from Artemisia iwayomogi and their effects on osteoblastic MC3T3-E1 cells," Biological and Pharmaceutical Bulletin, vol. 33, no. 8, pp. 1448-1453, 2010.

[146] L. Yang, Q. Chen, F. Wang, and G. Zhang, "Antiosteoporotic compounds from seeds of Cuscuta chinensis," Journal of Ethnopharmacology, vol. 135, no. 2, pp. 553-560, 2011.

[147] H. M. Yang, H. K. Shin, Y. H. Kang, and J. K. Kim, “Cuscuta chinensis extract promotes osteoblast differentiation and mineralization in human osteoblast-like MG-63 cells," Journal of Medicinal Food, vol. 12, no. 1, pp. 85-92, 2009.

[148] Y. J. Ko, J. B. Wu, H. Y. Ho, and W. C. Lin, "Antiosteoporotic activity of Davallia formosana," Journal of Ethnopharmacology, vol. 139, pp. 558-565, 2012.

[149] X. Zhao, Z. X. Wu, Y. Zhang et al., "Anti-osteoporosis activity of Cibotium barometz extract on ovariectomy-induced bone loss in rats," Journal of Ethnopharmacology, vol. 137, no. 3, pp. 1083-1088, 2011.
[150] K. Y. Peng, L. Y. Horng, H. C. Sung, H. C. Huang, and R. T. Wu, "Antiosteoporotic activity of Dioscorea alata L. cv. phyto through driving mesenchymal stem cells differentiation for bone formation," Evidence-Based Complementary and Alternative Medicine, vol. 2011, Article ID 712892, 12 pages, 2011.

[151] J. Yin, Y. Tezuka, K. Kouda et al., "Antiosteoporotic activity of the water extract of Dioscorea spongiosa," Biological and Pharmaceutical Bulletin, vol. 27, no. 4, pp. 583-586, 2004.

[152] J. Yin, Y. Tezuka, K. Kouda et al., "In vivo antiosteoporotic activity of a fraction of Dioscorea spongiosa and its constituent, 22-O-methylprotodioscin," Planta Medica, vol. 70, no. 3, pp. 220-226, 2004.

[153] Z. G. Liu, R. Zhang, C. Li et al., "The osteoprotective effect of Radix Dipsaci extract in ovariectomized rats," Journal of Ethnopharmacology, vol. 123, no. 1, pp. 74-81, 2009.

[154] L. Devareddy, S. Hooshmand, J. K. Collins, E. A. Lucas, S. C. Chai, and B. H. Arjmandi, "Blueberry prevents bone loss in ovariectomized rat model of postmenopausal osteoporosis," Journal of Nutritional Biochemistry, vol. 19, no. 10, pp. 694699, 2008.

[155] H. Ha, J. Ho, S. Shin et al., "Effects of Eucommiae cortex on osteoblast-like cell proliferation and osteoclast inhibition," Archives of Pharmacal Research, vol. 26, no. 11, pp. 929-936, 2003.

[156] R. Zhang, Z. G. Liu, C. Li et al., "Du-Zhong (Eucommia ulmoides Oliv.) cortex extract prevent OVX-induced osteoporosis in rats," Bone, vol. 45, no. 3, pp. 553-559, 2009.

[157] Y. Li, M. J. Wang, S. Li et al., "Effect of total glycosides from Eucommia ulmoides seed on bone microarchitecture in rats," Phytotherapy Research, vol. 25, no. 12, pp. 1895-1897, 2011.

[158] L. Penolazzi, I. Lampronti, M. Borgatti et al., "Induction of apoptosis of human primary osteoclasts treated with extracts from the medicinal plant Emblica officinalis," BMC Complementary and Alternative Medicine, vol. 8, article no. 59, pp. 59-71, 2008.

[159] Y. Zhang, Q. Li, X. Li, H. Y. Wan, and M. S. Wong, "Erythrina variegata extract exerts osteoprotective effects by suppression of the process of bone resorption," British Journal of Nutrition, vol. 104, no. 7, pp. 965-971, 2010.

[160] Y. Zhang, X. L. Li, W. P. Lai et al., "Anti-osteoporotic effect of Erythrina variegata L. in ovariectomized rats," Journal of Ethnopharmacology, vol. 109, no. 1, pp. 165-169, 2007.

[161] I. Dontas, M. Halabalaki, P. Moutsatsou et al., "Protective effect of plant extract from Onobrychis ebenoides on ovariectomy-induced bone loss in rats," Maturitas, vol. 53, no. 2, pp. 234-242, 2006.

[162] M. Halabalaki, X. Alexi, N. Aligiannis et al., "Estrogenic activity of isoflavonoids from Onobrychis ebenoides," Planta Medica, vol. 72, no. 6, pp. 488-493, 2006.

[163] Z. Papoutsi, E. Kassi, D. Papaevangeliou et al., "Plant 2arylobenzofurans demonstrate a selective estrogen receptor modulator profile," Steroids, vol. 69, no. 11-12, pp. 727-734, 2004.

[164] J. Kim, S. J. Um, J. Woo et al., "Comparative effect of seeds of Rhynchosia volubilis and soybean on MG-63 human osteoblastic cell proliferation and estrogenicity," Life Sciences, vol. 78, no. 1, pp. 30-40, 2005.

[165] S. S. Joo, T. J. Won, H. C. Kang, and D. I. Lee, "Isoflavones extracted from Sophorae fructus upregulate IGF-I and TGF$\beta$ and inhibit osteoclastogenesis in rat born marrow cells," Archives of Pharmacal Research, vol. 27, no. 1, pp. 99-105, 2004. 
[166] S. S. Joo, H. C. Kang, M. W. Lee, Y. W. Choi, and D. I. Lee, "Inhibition of IL-1beta and IL-6 in osteoblast-like cell by isoflavones extracted from Sophorae fructus," Archives of Pharmacal Research, vol. 26, no. 12, pp. 1029-1035, 2003.

[167] R. Pandey, A. K. Gautam, B. Bhargavan et al., "Total extract and standardized fraction from the stem bark of Butea monosperma have osteoprotective action: evidence for the nonestrogenic osteogenic effect of the standardized fraction," Menopause, vol. 17, no. 3, pp. 602-610, 2010.

[168] S. S. Shirke, S. R. Jadhav, and A. G. Jagtap, "Osteoprotective effect of Phaseolus vulgaris $\mathrm{L}$ in ovariectomy-induced osteopenia in rats," Menopause, vol. 16, no. 3, pp. 589-596, 2009.

[169] L. M. F. Lucinda, B. J. Vieira, T. T. Oliveira et al., "Evidences of osteoporosis improvement in Wistar rats treated with Ginkgo biloba extract: a histomorphometric study of mandible and femur," Fitoterapia, vol. 81, no. 8, pp. 982-987, 2010.

[170] S. M. Oh, H. R. Kim, and K. H. Chung, "Effects of Ginkgo biloba on in vitro osteoblast cells and ovariectomized rat osteoclast cells," Archives of Pharmacal Research, vol. 31, no. 2, pp. 216-224, 2008.

[171] Z. Papoutsi, E. Kassi, I. Chinou, M. Halabalaki, L. A. Skaltsounis, and P. Moutsatsou, "Walnut extract (Juglans regia L.) and its component ellagic acid exhibit anti-inflammatory activity in human aorta endothelial cells and osteoblastic activity in the cell line KS483," British Journal of Nutrition, vol. 99, no. 4, pp. 715-722, 2008.

[172] Y. Ono, Y. Fukaya, S. Imai, and T. Yamakuni, "Beneficial effects of Ajuga decumbens on osteoporosis and arthritis," Biological and Pharmaceutical Bulletin, vol. 31, no. 6, pp. 1199-1204, 2008.

[173] K. H. Lee and E. M. Choi, "Stimulatory effects of extract prepared from the bark of Cinnamomum cassia blume on the function of osteoblastic MC3T3-E1 cells," Phytotherapy Research, vol. 20, no. 11, pp. 952-960, 2006.

[174] C. H. Tang, T. H. Huang, C. S. Chang, W. M. Fu, and R. S. Yang, "Water solution of onion crude powder inhibits RANKL-induced osteoclastogenesis through ERK, p38 and NF- $\kappa$ B pathways," Osteoporosis International, vol. 20, no. 1, pp. 93-103, 2009.

[175] M. Mukherjee, A. S. Das, S. Mitra, and C. Mitra, "Prevention of bone loss by oil extract of garlic (Allium sativum Linn.) in an ovariectomized rat model of osteoporosis," Phytotherapy Research, vol. 18, no. 5, pp. 389-394, 2004.

[176] H. Nian, L. P. Qin, W. S. Chen, Q. Y. Zhang, H. C. Zheng, and Y. Wang, "Protective effect of steroidal saponins from rhizome of Anemarrhena asphodeloides on ovariectomyinduced bone loss in rats," Acta Pharmacologica Sinica, vol. 27, no. 6, pp. 728-734, 2006.

[177] G. F. Zeng, Z. Y. Zhang, L. Lu et al., "Protective effects of Polygonatum sibiricum polysaccharide on ovariectomyinduced bone loss in rats," Journal of Ethnopharmacology, vol. 136, no. 1, pp. 224-229, 2011.

[178] N. Ayoub, A. N. Singab, M. El-Naggar, and U. Lindequist, "Investigation of phenolic leaf extract of Heimia myrtifolia (Lythraceae): pharmacological properties (stimulation of mineralization of SaOS-2 osteosarcoma cells) and identification of polyphenols," Drug Discoveries and Therapeutics, vol. 4, no. 5, pp. 341-348, 2010.

[179] C. Puel, J. Mathey, S. Kati-Coulibaly et al., "Preventive effect of Abelmoschus manihot (L.) Medik. on bone loss in the ovariectomised rats," Journal of Ethnopharmacology, vol. 99, no. 1, pp. 55-60, 2005.
[180] P. Kapur, H. Jarry, W. Wuttke, B. M. J. Pereira, and D. Seidlova-Wuttke, "Evaluation of the antiosteoporotic potential of Tinospora cordifolia in female rats," Maturitas, vol. 59, no. 4, pp. 329-338, 2008.

[181] A. N. Shuid, L. L. Ping, N. Muhammad, N. Mohamed, and I. N. Soelaiman, "The effects of Labisia pumila var. alata on bone markers and bone calcium in a rat model of postmenopausal osteoporosis," Journal of Ethnopharmacology, vol. 133, no. 2, pp. 538-542, 2011.

[182] Y. Zhang, W. P. Lai, P. C. Leung, C. F. Wu, X. S. Yao, and M. S. Wong, "Effects of Fructus Ligustri Lucidi extract on bone turnover and calcium balance in ovariectomized rats," Biological and Pharmaceutical Bulletin, vol. 29, no. 2, pp. 291296, 2006.

[183] X. L. Dong, Y. Zhang, M. J. Favus, C. T. Che, and M. S. Wong, "Ethanol extract of Fructus Ligustri Lucidi increases circulating 1,25-dihydroxyvitamin D3 by inducing renal 25hydroxyvitamin D- $1 \alpha$ hydroxylase activity," Menopause, vol. 17, no. 6, pp. 1174-1181, 2010.

[184] K. Masuda, M. Ikeuchi, T. Koyama et al., "Suppressive effects of Anoectochilus formosanus extract on osteoclast formation in vitro and bone resorption in vivo," Journal of Bone and Mineral Metabolism, vol. 26, no. 2, pp. 123-129, 2008.

[185] H. Liang, F. Yu, Z. Tong, and Z. Huang, "Effect of cistanches herba aqueous extract on bone loss in ovariectomized rat," International Journal of Molecular Sciences, vol. 12, no. 8, pp. 5060-5069, 2011.

[186] S. W. Kim, H. G. Kim, B. E. Lee, H. H. Hwang, D. H. Baek, and S. Y. Ko, "Effects of mushroom, Pleurotus eryngii, extracts on bone metabolism," Clinical Nutrition, vol. 25, no. 1, pp. 166-170, 2006.

[187] J. Mori-Okamoto, Y. Otawara-Hamamoto, H. Yamato, and H. Yoshimura, "Pomegranate extract improves a depressive state and bone properties in menopausal syndrome model ovariectomized mice," Journal of Ethnopharmacology, vol. 92, no. 1, pp. 93-101, 2004.

[188] J. X. Li, J. Liu, C. C. He et al., "Triterpenoids from Cimicifugae rhizoma, a novel class of inhibitors on bone resorption and ovariectomy-induced bone loss," Maturitas, vol. 58, no. 1, pp. 59-69, 2007.

[189] S. Hooshmand, S. C. Chai, R. L. Saadat, M. E. Payton, K. Brummel-Smith, and B. H. Arjmandi, "Comparative effects of dried plum and dried apple on bone in postmenopausal women," British Journal of Nutrition, vol. 106, no. 6, pp. 923930, 2011.

[190] B. H. Arjmandi, C. D. Johnson, S. C. Campbell, S. Hooshmand, S. C. Chai, and M. P. Akhter, "Combining fructooligosaccharide and dried plum has the greatest effect on restoring bone mineral density among select functional foods and bioactive compounds," Journal of Medicinal Food, vol. 13, no. 2, pp. 312-319, 2010.

[191] K. H. Lee and E. M. Choi, "Rubus coreanus Miq. extract promotes osteoblast differentiation and inhibits bone-resorbing mediators in MC3T3-E1 cells," American Journal of Chinese Medicine, vol. 34, no. 4, pp. 643-654, 2006.

[192] S. H. Do, J. W. Lee, W. I. Jeong et al., "Bone-protecting effect of Rubus coreanus by dual regulation of osteoblasts and osteoclasts," Menopause, vol. 15, no. 4, pp. 676-683, 2008.

[193] B. Y. Kim, H. Y. Yoon, S. I. Yun et al., "In vitro and in vivo inhibition of glucocorticoid-induced osteoporosis by the hexane extract of Poncirus trifoliata," Phytotherapy Research, vol. 25, no. 7, pp. 1000-1010, 2011.

[194] F. Deyhim, K. Mandadi, B. S. Patil, and B. Faraji, "Grapefruit pulp increases antioxidant status and improves bone quality 
in orchidectomized rats," Nutrition, vol. 24, no. 10, pp. 10391044, 2008.

[195] F. Deyhim, K. Mandadi, B. Faraji, and B. S. Patil, "Grapefruit juice modulates bone quality in rats," Journal of Medicinal Food, vol. 11, no. 1, pp. 99-104, 2008.

[196] K. O. Oh, S. W. Kim, J. Y. Kim et al., "Effect of Rehmannia glutinosa Libosch extracts on bone metabolism," Clinica Chimica Acta, vol. 334, no. 1-2, pp. 185-195, 2003.

[197] P. R. Nagareddy and M. Lakshmana, "Withania somnifera improves bone calcification in calcium-deficient ovariectomized rats," Journal of Pharmacy and Pharmacology, vol. 58, no. 4, pp. 513-519, 2006.

[198] C. K. Park, H. J. Kim, H. B. Kwak et al., "Inhibitory effects of Stewartia koreana on osteoclast differentiation and bone resorption," International Immunopharmacology, vol. 7, no. 12, pp. 1507-1516, 2007.

[199] S. K. Kang, K. S. Kim, Y. S. Byun et al., "Effects of Ulmus davidiana planch on mineralization, bone morphogenetic protein-2, alkaline phosphatase, type I collagen, and collagenase-1 in bone cells," In Vitro Cellular and Developmental Biology, vol. 42, no. 7, pp. 225-229, 2006.

[200] J. A. Siddiqui, K. Sharan, G. Swarnkar et al., "Quercetin6-C- $\beta$-d-glucopyranoside isolated from Ulmus wallichiana planchon is more potent than quercetin in inhibiting osteoclastogenesis and mitigating ovariectomy-induced bone loss in rats," Menopause, vol. 18, no. 2, pp. 198-207, 2011.

[201] K. Sharan, G. Swarnkar, J. A. Siddiqui et al., "A novel flavonoid, 6-C- $\beta$-d-glucopyranosyl-(2S,3S)-(+)-3', 4',5,7tetrahydroxyflavanone, isolated from Ulmus wallichiana Planchon mitigates ovariectomy-induced osteoporosis in rats," Menopause, vol. 17, no. 3, pp. 577-586, 2010.

[202] G. Swarnkar, K. Sharan, J. A. Siddiqui et al., "A novel flavonoid isolated from the steam-bark of Ulmus wallichiana Planchon stimulates osteoblast function and inhibits osteoclast and adipocyte differentiation," European Journal of Pharmacology, vol. 658, no. 2-3, pp. 65-73, 2011.

[203] K. Sharan, J. A. Siddiqui, G. Swarnkar et al., "Extract and fraction from Ulmus wallichiana Planchon promote peak bone achievement and have a nonestrogenic osteoprotective effect," Menopause, vol. 17, no. 2, pp. 393-402, 2010.

[204] S. Sehmisch, J. Boeckhoff, J. Wille et al., "Vitex agnus castus as prophylaxis for osteopenia after orchidectomy in rats compared with estradiol and testosterone supplementation," Phytotherapy Research, vol. 23, no. 6, pp. 851-858, 2009.

[205] A. Shirwaikar, S. Khan, and S. Malini, "Antiosteoporotic effect of ethanol extract of Cissus quadrangularis Linn. on ovariectomized rat," Journal of Ethnopharmacology, vol. 89, no. 2-3, pp. 245-250, 2003.

[206] S. Muthusami, K. Senthilkumar, C. Vignesh et al., "Effects of Cissus quadrangularis on the proliferation, differentiation and matrix mineralization of human osteoblast like SaOS2 cells," Journal of Cellular Biochemistry, vol. 112, no. 4, pp. 1035-1045, 2011.

[207] S. Muthusami, I. Ramachandran, S. Krishnamoorthy, R. Govindan, and S. Narasimhan, "Cissus quadrangularis augments IGF system components in human osteoblast like SaOS-2 cells," Growth Hormone and IGF Research, vol. 21, no. 6, pp. 343-348, 2011.

[208] J. Weerachayaphorn, A. Chuncharunee, C. Mahagita, B. Lewchalermwongse, A. Suksamrarn, and P. Piyachaturawat, "A protective effect of Curcuma comosa Roxb. on bone loss in estrogen deficient mice," Journal of Ethnopharmacology, vol. 137, no. 2, pp. 956-962, 2011.
[209] S. Oh, T. W. Kyung, and H. S. Choi, "Curcumin inhibits osteoclastogenesis by decreasing receptor activator of nuclear factor- $\kappa \mathrm{B}$ ligand (RANKL) in bone marrow stromal cells," Molecules and Cells, vol. 26, no. 5, pp. 486-489, 2008. 


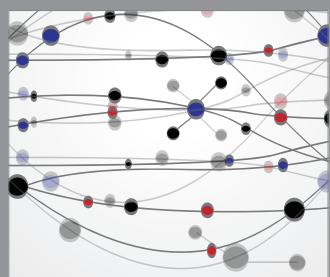

The Scientific World Journal
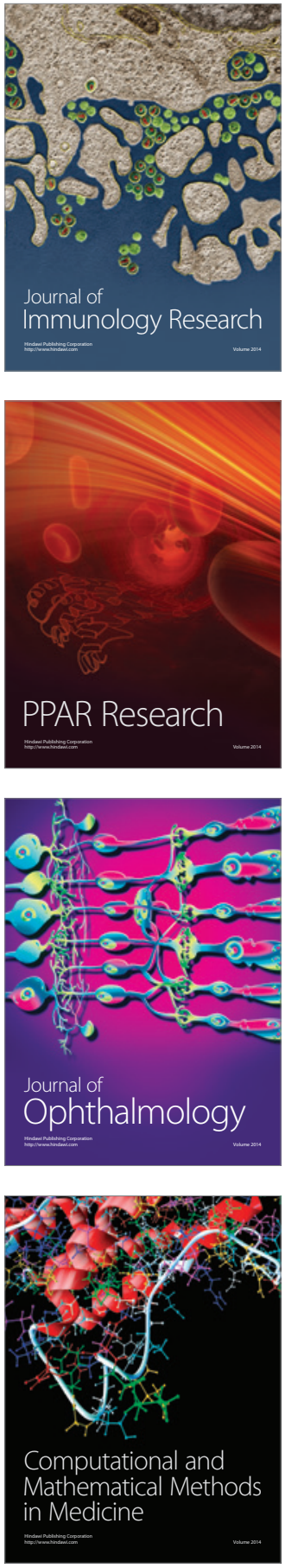

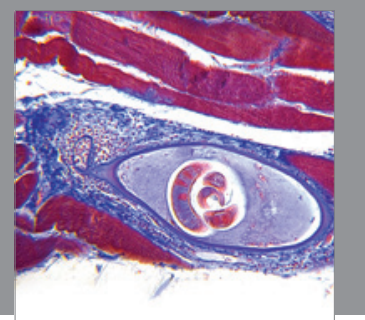

Gastroenterology

Research and Practice
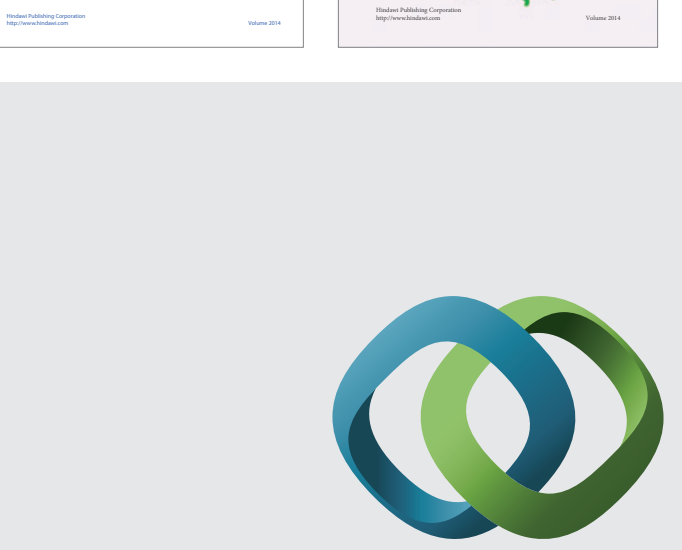

\section{Hindawi}

Submit your manuscripts at

http://www.hindawi.com
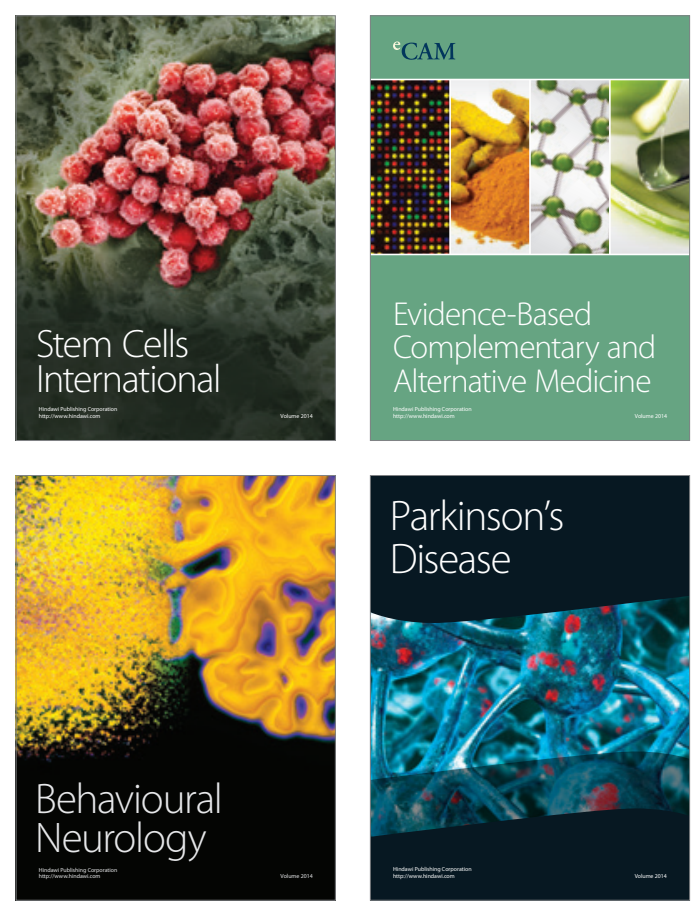

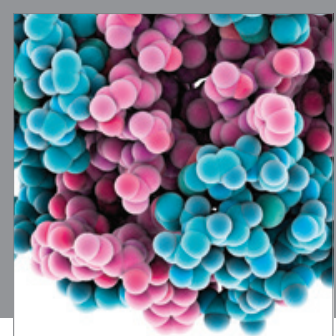

Journal of
Diabetes Research

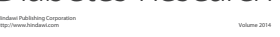

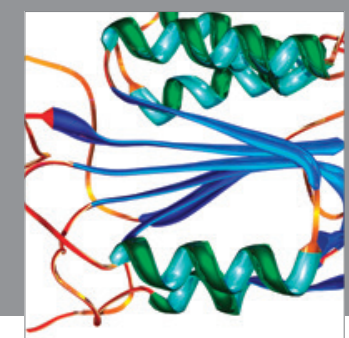

Disease Markers
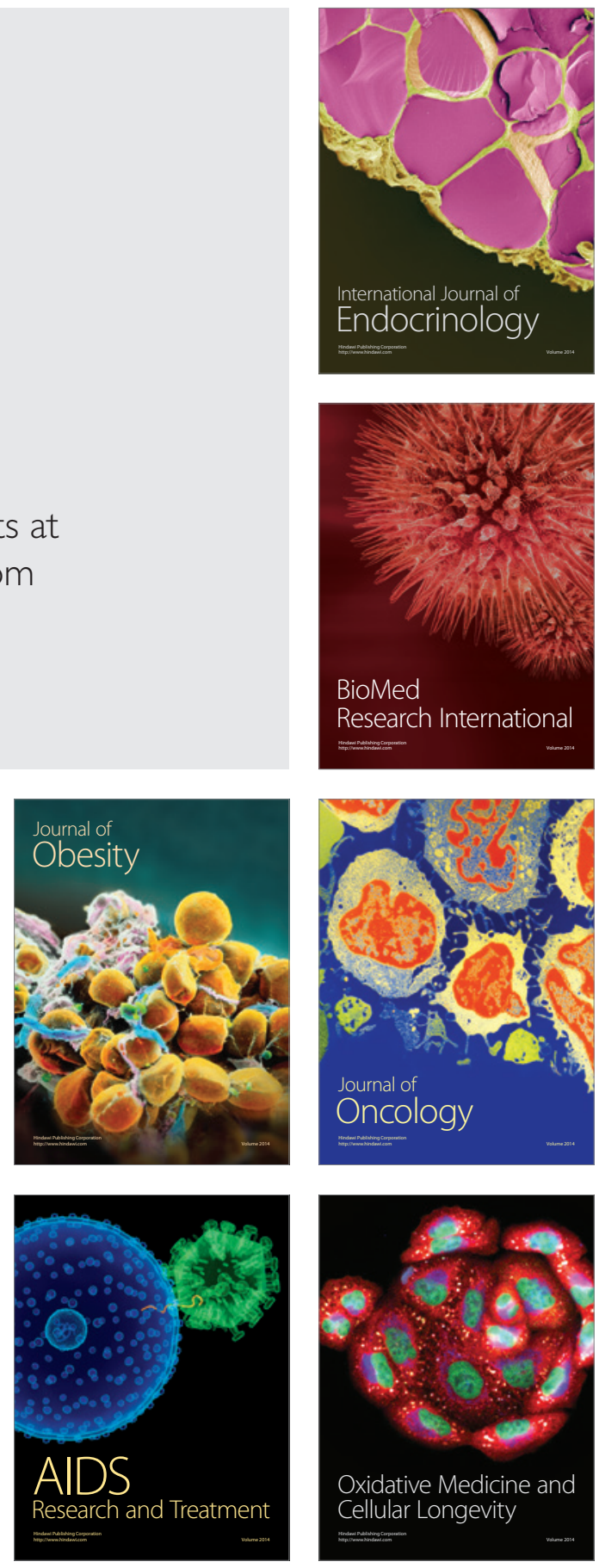